Article

\title{
Generational Differences toward Organic Food Behavior: Insights from Five Generational Cohorts
}

\author{
Irene (Eirini) Kamenidou ${ }^{1, *}$, Aikaterini Stavrianea ${ }^{2}$ and Evangelia-Zoi Bara ${ }^{1}$ \\ 1 Department of Management Science and Technology, International Hellenic University, Kavala Campus, \\ 65404 Agios Loukas Kavala, Greece; evaeva13@hotmail.gr \\ 2 Department of Communication and Media Studies, National and Kapodistrian University of Athens, \\ 10562 Athens, Greece; aikstavria@media.uoa.gr \\ * Correspondence: rkam@mst.ihu.gr; Tel.: +30-2510-462157
}

Received: 29 December 2019; Accepted: 12 March 2020; Published: 15 March 2020

check for updates

\begin{abstract}
One of the pathways to sustainable food consumption behaviour is the purchase and consumption of organic food products. This paper offers insights into the behaviour exercised by five generational cohorts toward organic products, i.e., Generation Z, Generation Y, Generation X, Baby Boomers, and the Silent Generation. A qualitative and quantitative research methodology is implemented, with the field research providing 1562 valid questionnaires over a nine-month period. Generational differences are explored in terms of purchasing behaviour, attitudes, and the effect of the economic crisis on the purchasing of organic food. Results unveil that all generational cohorts demonstrate a favourable attitude toward organic food, and they identify the economic crisis as an effect of low purchase behaviour. Additionally, findings reveal that in all cases, generational cohort differences do exist. Government policy through marketing communications can be adapted to determine the advantages of organic food compared to conventional ones, persuade consumers about the benefits, and, thus, reinforce favourable attitudes in association with economic crisis conditions.

Keywords: sustainable food consumption; organic food; multigenerational cohorts; consumer behavior; Generation Z; Generation Y; Generation X; Baby Boomers; Silent Generation; marketing communications
\end{abstract}

\section{Introduction}

For preserving natural resources, consumer's sustainable food behaviour deems to be imperative, since consumers' food consumption choices have both an indirect and direct impact on the environment [1-3] and, as such, they carry immense importance from an environmental prism [4].

Sustainable food consumption (SFC) is a subset of sustainable consumer behaviour. Trudel [5] (p. 85) considers sustainable consumer behaviour as "a behaviour that attempts to satisfy present needs while simultaneously benefiting or limiting environmental impact". Moreover, sustainable consumer behaviour falls under the umbrella of consumer behaviour, which as Kotler and Keller [6] define, is the study of how individuals, groups, and organizations select, buy, use, and dispose of goods, services, and ideas to satisfy their needs and wants. Thus, sustainable consumer behaviour includes both actions and the attitudes, preferences, and motives that lead to actions.

The significance of food consumption in a sustainable manner has triggered academics' interest globally, yielding ample research articles that have been compiled from very diverse points of view.

One focal point of interest relates to the environmental benefits associated with the adoption of sustainable food behaviour (SFB), which originate from three axons, i.e., from consumers (directly or indirectly through derivative demand), agriculture, and industry [7]. Some of the environmental benefits recorded in academia refer to the reduction of greenhouse-gas emissions, i.e., greenhouse gas 
(GHG) emissions [8], reduction of the ecological footprint of agricultural or food products [9], less household waste, avoidance of soil degradation [7], and the general protection of the ecosystem [10]. As regards the dimensions of SFB that produce environmental benefits, these as recorded by previous researchers are decrease in meat consumption, increase of fruit and vegetable consumption, substitution of meat protein by other type of proteins or insects, purchase and consumption of local products, avoidance of imported food, avoidance of excess packages, and consumption of organic food [11-14]. Especially for the latter (i.e., consumption of organic food as a dimension of SFC), a rich literature is found [15]. In this specific domain, vast scholarly work has emphasized building consumer profiles [16], developing typologies [17], predicting consumers behaviour [18], as well as describing extensively a varied spectrum of motives and barriers related to purchasing and consumption of organic food [19]. Specifically, previous research has demonstrated that attitudes and income $[20,21]$ are associated with organic food purchasing behaviour. Among the prevailing barriers of organic food consumption (OFC) identified, one can find the individual or family income constraints, with only a limited number of studies referring directly to consumers' behavioural change due to economic crisis conditions [22-24], which can directly influence consumers' income. Specifically, Schaack et al. [25] stated that in 2013 the organic market in Greece (where this research took place) had "declined substantially" due to the fiscal crisis, though no further evidence was made publicly available. Research also has shown that in the time of the Greek fiscal crisis, households do not trust the quality controls implemented by government authorities, considering them as being incomplete or defective [26]. Therefore, the economic barrier affecting behaviour toward organic food may be overcome by health perceptions derived from food safety issues. Specifically, Kamenidou et al. [26] when researching food security issues of 1305 households found that in Greece during the fiscal crisis, households believed that the control structures of the government associated with food safety and hygiene were inefficient. Hence, the issue of economic crisis and its impact on Greek consumers behaviour is considered of interest for investigation due to contradictory effects on organic food behaviour.

Therefore, this research paper draws data from Greece, a European country which, for 11 consecutive years, has experienced an economic crisis. In the 11 years (2010-2020) of the continuous crisis in the Greek economy and the country's failure to bail out, four different governments have signed four subsequent Memoranda of Understanding (MOUs) with TROIKA (group formed by the European Commission, the European Central Bank, and the International Monetary Fund) in the years 2010, 2012, 2015, and 2017, implementing continuous cut-offs as austerity measures, and structural reforms. Compared to 2009, the year before the first MOU was signed, (some of) the effects reported in economy and society could be summarized as follows: Greece's GDP in terms of current prices (billion $€$ ) decreased from 237.4 in 2009 to 184.7 in 2018 [27]. Poverty rose from $27.7 \%$ (2009) to $34.8 \%$ in 2016, being the third in line poverty country of the EU-28 countries [28]. Additionally, from the 7 May 2010 (the day after the first Memorandum was voted) up to 1 February 2020, about one third of a million $(331,279)$ businesses terminated their function according to General Commercial Registry [29]. The unemployment rate rose from 9.4\% (2009) to $23.6 \%$ (2016), being the highest in the European Union [30]. Extreme brain waste [31] and brain drain [32] were also recorded, while excessive cut-offs and pension adjustments were experienced in the Greek public sector, resulting in more than 180,000 public servants resigning from 2010 to 2015 [33].

Additionally, although a plethora of studies focus on OFC under the umbrella of sustainability, studies on consumer organic food behaviour (OFB) that adopt the generational cohort theory are still limited in number and spectrum as they examine merely one cohort [34], while, no studies have been retrieved that focus simultaneously on organic food purchase, attitude, economic crisis, and generational cohorts (to our knowledge).

Generational cohorts are composed of people who are born within a certain time period and at a specific place, and have experienced identical life-changing events at their "coming of age", i.e., when they are 17-23 years old [35]. Generational cohorts differ from generations, which exclusively rely upon time periods and are 20-25 years apart [36]. Even though scholars principally agree on the 
presence of generational cohorts and provide in-depth analysis of cohort characteristics [37-39], there is considerable disagreement about the period and name of each generational cohort, especially following the Baby Boomer generation [38-41]. Generational cohorts are used today in consumer marketing, and it is considered as a new way of market segmentation, since "cohort effects are lifelong effects", as Schewe and Meredith [42] identify. Additionally, Pitta et al. [43] ascertain that the use of generational cohorts as a segmentation variable is more effective than gender, income, and education, while Schewe and Meredith [42] pinpoint that generational cohorts are useful for communication campaigns.

Overall, generational cohort marketing has been recognized as a very effective approach due to the consistent behaviour of cohorts attested [44] and is strongly documented in the work of various scholars [45]. Academics ascertain that each generational cohort differs from the others in behaviour, while at the same time they identify common behavioural patterns between people who belong to the same cohort [46]. Therefore, given that the corresponding literature on the subject is extremely limited, it becomes critical to investigate the various generational cohorts as this has developed into an emerging and controversial topic in the Marketing domain. Consequently, while generational cohort theory was utilized at first only in four countries (the US, Canada, England, Australia), it has been rapidly adopted by other countries too mainly due to its high importance in consumer marketing [11,47-51].

With respect to the study population, the targeted sample group of the present study consists of five Greek generational cohorts, namely the Silent Generation, the Baby Boomers, Generation X, Generation Y, and the Generation Z cohort.

Tangermann [52] points out that today consumers are interested in sustainable food choices, but much must be achieved from the governments' side, as they cannot pass on their responsibility to consumers. Sedlacko et al. [53] point out that issues which lead to unsustainable global food consumption will get worse in the future, while policymakers take actions for SFC due to the "growing scientific understanding" of these problems. Consequently, it is of extreme value to examine through the prism of organic food choices, the OFB expressed by multiple generational cohorts, as these may provide further understanding of the country's total sustainable behaviour. In addition, these insights may lead to appropriate sustainable policies established by governments in order to ensure a sustainable future. The five generational cohorts examined in this research cover the age spectrum of approximately the total adult population of the country since it provides insight for people aged between 18 and 95 years old, also revealing the tendency of the country's sustainable future. Policymakers having information regarding the behaviour of these cohorts at their disposal, may implement specific campaigns and actions targeting certain generational cohorts.

Therefore, in this context the following research questions (RQs) have arisen:

- RQ1: Do the different generational cohorts purchase organic food, and how often do they purchase it?

- RQ2: What kind of attitudes does each generation hold toward organic food?

- RQ3: Does the economic crisis affect each generation's purchasing behaviour toward organic food products?

- $\quad$ RQ4: Are any generational differences observed in OFB (attitudes, economic crisis impact, and purchasing behaviour of organic food)?

- $\quad$ RQ5: If so, which generational cohorts differ in OFB?

- RQ6: What actions could government policymakers implement, and what marketing techniques can they utilize in order to try to change consumers' OFB in a positive manner?

Against this background, the present paper aims to explore organic food behaviour among multiple generational cohorts ( $\geq 2$ simultaneously), specifically looking for differences in behaviour among these cohorts. More precisely, its objectives are to investigate the following issues:

1. The self-reported Greek generational cohorts' purchasing behaviour of organic food.

2. The attitudes that each generation holds toward organic food. 
3. The effect of the economic crisis on each generation's purchasing behaviour toward organic food products.

4. Generational differences observed in OFB (attitudes, economic crisis impact, and purchasing behaviour of organic food).

5. The specific generational cohort differences in OFB.

6. Based on the results of data analysis, to suggest actions and marketing communication techniques for policymakers in order to produce as an outcome favourable OFB.

Prior researches have extensively addressed SFC and organic food topics; yet, the additional contribution the present scholarly work makes is that it aims to raise and address the following neglected areas attested in the relevant literature:

1. It focuses simultaneously on multiple generational cohort consumers, covering (i) Generation $Z$ (Gen Z), (ii) Generation Y (Gen Y), (iii) Generation X (Gen X), (iv) Baby Boomers (BB), and (v) the Silent Generation (SG).

2. Studying consumers' patterns based on their generational cohort is an emerging topic in the marketing field $[11,54,55]$ and-compared to other consumer characteristics-it is an understudied topic. As Chaney et al. [55] state, generational cohorts, while used widely in social sciences, in the marketing area, this concept has been studied "marginally".

3. It focuses on multigenerational OFB ( $\geq 2$ generational cohorts), which is a rather neglected subject (as to the authors' knowledge, no prior study has been found), inflicting the need for more research.

4. It provides insights from self-reported purchasing behaviour as stated by different generational cohorts. While several studies have been retrieved that refer to organic food behaviour and generational cohort, these focus only on a single cohort (mainly generation $\mathrm{Y}$ ), and in their vast majority, these predict future behaviour (mainly through the TPB model) and not the present and the actual one e.g., [56,57].

5. It provides an in-depth understanding of research associated with consumers' food purchasing behaviour within the Greek fiscal crisis, which had not been thoroughly studied previously, and for so, that aspect also necessitates further investigation [58].

6. It raises topics strongly related to different generational cohorts' attitudes toward organic food and the impact of the economic crisis on them for which no prior studies exist to the authors' knowledge.

In order to challenge the abovementioned aim and objectives of the current study, research on multiple levels was implemented (i.e., desk, qualitative, and field research), while in terms of structure, the present paper has the following layout: the next section briefly presents the generational cohort theory as well as a critical literature review regarding the subject under analysis, followed by the implemented materials and methods. Then, the results of the study combined with the thorough discussion are presented, finishing with the authors' conclusions and recommendations to policymakers. The authors also present the limitations and directions for further research that this work could lead to.

\section{Literature Review}

While multigenerational cohort studies or cross-generational studies have been detected in different areas of academic research, most of the studies focus on generational differences in the workplace [59-61]. Yet, other academic fields also encompass cross-generational differences, such as the travel and tourism industry [62-65]; the health, mental, cognition, or psychology sector examining related issues [66-68]; the service sector [69-71]; and studies in education [72,73]. Moreover, cross-generational differences were studied in retailing regarding products in the non-food sector [74-77], in technology adoption or purchase [78,79], as well as politics [80]. Finally, several academic papers were detected in the food and beverage sector (non-organic) and multigenerational differences [81-83]. 
On the other hand, multiple academic papers [14-16,84-86] have dealt extensively with organic food and consumer behaviour. All these studies focus on different aspects, diverse issues, and specific organic food. Examples consist of studies centred on organic meat, fruits and vegetables, fish, as well as organic dairy products [87-90]. In this domain, different aspects of consumer behaviour, such as predicting behaviour or providing motives and barriers, have been also addressed [19,91,92]. Additionally, another significant part of existing research provides readers with consumer segments based on different variables, ranging from attitudes to consumer characteristics, profiling consumers of organic food, and/or developing typologies [17,93-95]. Moreover, previous authors have provided an extensive review of the literature in association with SFC and/or organic food behaviour [96-100], and a few studies have focused exclusively on OFB in connection with an economic downturn, crisis, or recession [22-24,101].

Studies that have focused on or include generational cohorts and SFC, and/or organic food products in general or specifically, are limited (to our knowledge), and they emphasize on one generation, with a particular tendency to Gen Y/Millennials [11,34,57,102-114]. Table 1 presents the studies that- to the author's knowledge-focus on SFC or OFB combined with generational cohorts.

Table 1. Studies on sustainable food consumption (SFC) or organic food behaviour (OFB) and generational cohorts.

\begin{tabular}{|c|c|c|c|c|}
\hline Authors & $\begin{array}{l}\text { Generational } \\
\text { Cohort }\end{array}$ & Issue/Variables & Country/Data & Findings \\
\hline $\begin{array}{l}\text { Molinillo et al. } \\
\text { [102] }\end{array}$ & Y/Millennials & $\begin{array}{l}\text { Antecedents of organic food } \\
\text { purchasing }\end{array}$ & $\begin{array}{l}\text { Brazil vs. Spain } \\
267 \text { Brazilians and } \\
263 \text { Spanish }\end{array}$ & $\begin{array}{l}\text { Characteristics of the product and } \\
\text { consumer's concern influence social } \\
\text { and health consciousness, which } \\
\text { affect the frequency and willingness } \\
\text { to pay more for organic food. }\end{array}$ \\
\hline $\begin{array}{l}\text { Bollani et al. } \\
\text { [103] }\end{array}$ & Y/Millennials & $\begin{array}{l}\text { Perception of the } \\
\text { connotation of sustainability } \\
\text { in the food domain }\end{array}$ & $\begin{array}{c}\text { Italy, } \mathrm{N}=268 \\
\text { University students }\end{array}$ & $\begin{array}{l}\text { Four groups of Millennials: The first } \\
\text { pay attention to the social, economic, } \\
\text { and sustainable production of food, } \\
\text { the second on labelling systems, the } \\
\text { third on innovation, and the fourth is } \\
\text { not interested in the issue. }\end{array}$ \\
\hline $\begin{array}{l}\text { Leerattanakorn } \\
\text { et al. [104] }\end{array}$ & $\mathrm{Y}$ & $\begin{array}{c}\text { Green consumption } \\
\text { behaviour, willingness to } \\
\text { pay (WTP) price premium, } \\
\text { and factors influencing WTP } \\
\text { premium for organic food } \\
\text { (among other green } \\
\text { products) }\end{array}$ & Thailand, $\mathrm{N}=1200$ & $\begin{array}{l}\text { Gen } \mathrm{Y} \text { is concerned with green } \\
\text { consumption, and } 78 \% \text { is willing to } \\
\text { pay more for green products }\end{array}$ \\
\hline $\begin{array}{c}\text { Průša \& } \\
\text { Sadílek [34] }\end{array}$ & $\mathrm{Y}$ & $\begin{array}{l}\text { Perception of green } \\
\text { marketing }\end{array}$ & Prague, $N=520$ & $\begin{array}{l}\text { Four variables, i.e., environmentalism, } \\
\text { preference, payment and tolerance } \\
\text { affect green consumer behaviour. }\end{array}$ \\
\hline $\begin{array}{l}\text { Vidal-Branco } \\
\text { et al. [105] }\end{array}$ & Y/Millennials & $\begin{array}{l}\text { Drivers of purchase of } \\
\text { organic food }\end{array}$ & Brazil, $N=267$ & $\begin{array}{l}\text { Environmental concerns, accessibility, } \\
\text { fashion, and price fairness are found } \\
\text { to be drivers of purchasing frequency } \\
\text { of organic food. }\end{array}$ \\
\hline $\begin{array}{l}\text { Muposhi \& } \\
\text { Dhurup [106] }\end{array}$ & $\mathrm{Y}$ & $\begin{array}{l}\text { Attributes of organic } \\
\text { products leading to } \\
\text { purchase decisions }\end{array}$ & $\begin{array}{l}\text { South Africa, } \\
\mathrm{N}=16 \text { (qualitative) }\end{array}$ & $\begin{array}{c}\text { Price, quality, convenience, } \\
\text { availability, performance, and trust } \\
\text { affect choices of generation } \mathrm{Y} \\
\text { members }\end{array}$ \\
\hline $\begin{array}{l}\text { Hassan et al. } \\
\text { [107] }\end{array}$ & $\mathrm{Y}$ & $\begin{array}{l}\text { Purchasing intention toward } \\
\text { organic food } \\
\text { (perception-motivation) }\end{array}$ & Malaysia, $\mathrm{N}=226$ & $\begin{array}{l}\text { Concern for the environment, health } \\
\text { factors and value affect purchase } \\
\text { intention toward organic food }\end{array}$ \\
\hline $\begin{array}{l}\text { Muposhi et al. } \\
\text { [108] }\end{array}$ & $\mathrm{Y}$ & $\begin{array}{l}\text { Influence of the Social } \\
\text { Dilemma Theory (SDT) on } \\
\text { organic food behaviour }\end{array}$ & $\begin{array}{c}\text { South Africa, } \\
\mathrm{N}=16 \\
\text { College and } \\
\text { university students } \\
\text { (qualitative) }\end{array}$ & $\begin{array}{l}\text { Efficacy, trust, cost image, and } \\
\text { influence from peers are drivers of the } \\
\text { Social Dilemma Theory that affect } \\
\text { green purchase. }\end{array}$ \\
\hline
\end{tabular}


Table 1. Cont.

\begin{tabular}{|c|c|c|c|c|}
\hline Authors & $\begin{array}{l}\text { Generational } \\
\text { Cohort }\end{array}$ & Issue/Variables & Country/Data & Findings \\
\hline $\begin{array}{l}\text { Thambiah } \\
\text { et al. [109] }\end{array}$ & Y & $\begin{array}{l}\text { Organic food consumption } \\
\text { intention }\end{array}$ & $\begin{array}{l}\text { Malaysia, } \mathrm{N}=380 \\
\text { University students }\end{array}$ & $\begin{array}{l}\text { The majority of the generation } Y \\
\text { Malaysian consumers are familiar } \\
\text { with organic food. Knowledge, } \\
\text { familiarity, and price consciousness } \\
\text { affect the intention to buy organic } \\
\text { food. }\end{array}$ \\
\hline $\begin{array}{l}\text { Pomarici \& } \\
\text { Vecchio [110] }\end{array}$ & Y/Millennials & $\begin{array}{c}\text { Preferences and purchase } \\
\text { decisions of sustainable } \\
\text { wines }\end{array}$ & Italy, $\mathrm{N}=500$ & $\begin{array}{l}\text { Wine label associated with support of } \\
\text { social issues has a higher patronage } \\
\text { percentage. Also, older females living } \\
\text { in cities are more probable to buy } \\
\text { sustainable wine. }\end{array}$ \\
\hline Regine [111] & Y & $\begin{array}{l}\text { Relationship between the } \\
\text { preference for organic foods } \\
\text { and demographics }\end{array}$ & $\begin{array}{c}\text { USA, } \mathrm{N}=220 \\
\text { university students }\end{array}$ & $\begin{array}{l}\text { Demographic differences related to } \\
\text { gender, major of study, income, age, } \\
\text { ethnicity, and environmental } \\
\text { knowledge for some of the } \\
\text { hypotheses of the study. }\end{array}$ \\
\hline $\begin{array}{l}\text { Pearson et al. } \\
\text { [112] }\end{array}$ & $\mathrm{Y}$ & $\begin{array}{c}\text { Perception of sustainable } \\
\text { diet }\end{array}$ & $\begin{array}{c}\text { Australia } \mathrm{N}=30 \\
\text { university students } \\
\text { (Qualitative) }\end{array}$ & $\begin{array}{l}\text { There are many ways in which } \\
\text { consumers understand the term } \\
\text { sustainable diet. Additionally, } \\
\text { respondents offered a variety of } \\
\text { suggestions on how to improve } \\
\text { sustainable food purchase choices, } \\
\text { production and consumption of food. }\end{array}$ \\
\hline $\begin{array}{l}\text { Sa'ari et al. } \\
\text { [57] }\end{array}$ & Y/Millennials & $\begin{array}{c}\text { Influence of various factors } \\
\text { on intention to consume } \\
\text { organic food }\end{array}$ & $\begin{array}{l}\text { Malaysia, } \mathrm{N}=235 \\
\text { university students }\end{array}$ & $\begin{array}{l}\text { Perceived quality, trust, and concern } \\
\text { for the environment positively } \\
\text { influence the intention to consume } \\
\text { organic food. }\end{array}$ \\
\hline $\begin{array}{l}\text { Ntanos et al. } \\
\text { [113] }\end{array}$ & Y/Millennials & $\begin{array}{l}\text { Perceptions on the organic } \\
\text { products }\end{array}$ & Greece, $N=163$ & $\begin{array}{l}\text { Greek Millennials are generally } \\
\text { favourable for organic products. } \\
\text { Quality, certification, taste, variety, } \\
\text { and firm name are criteria to buy. }\end{array}$ \\
\hline $\begin{array}{l}\text { Kamenidou } \\
\text { et al. [11] }\end{array}$ & $\mathrm{Z}$ & $\begin{array}{l}\text { SFC behaviour of the } \\
\text { Generation } Z \text { cohort; } \\
\text { segmentation of cohort } Z\end{array}$ & $\begin{array}{c}\text { Greece, } N=252 \\
\text { university students }\end{array}$ & $\begin{array}{l}\text { Sustainable behaviour focuses on } \\
\text { eating seasonal fruits and vegetables } \\
\text { and purchasing regional products. } \\
\text { Two consumer segments were found. }\end{array}$ \\
\hline Su et al. [114] & $\mathrm{Z}$ & $\begin{array}{l}\text { Segmentation based on } \\
\text { environmental } \\
\text { consciousness and } \\
\text { sustainable food attributes }\end{array}$ & USA, $N=812$ & $\begin{array}{l}\text { High, moderate, and low } \\
\text { environmentally conscious groups } \\
\text { were found. The first two groups } \\
\text { considered health and environmental } \\
\text { elements when purchasing } \\
\text { sustainable food, and the third group } \\
\text { considered elements such as price and } \\
\text { convenience }\end{array}$ \\
\hline
\end{tabular}

The table above demonstrates that only 16 studies have been found regarding generational cohorts and SFC behaviour, or on generational cohorts and OFB. These studies refer to one generational cohort, mainly the Gen Y cohort, while generation cohort differences have not been examined since no study (to our knowledge) deals with multiple generational cohorts and cohort behaviour toward organic food. Thus, it justifies the necessity for a more profound investigation centred on SFC, OFB, and generational cohorts.

\section{Materials and Methods}

Within the above theoretical framework, this study examines five Greek generational cohorts, i.e., the Silent Generation born between 1925-1945 [37]; the Baby Boomers born between 1946 and 1964 [40]; Generation X, consisting of people born between 1965-1977 [40]; Generation Y (or millennials according to many scholars) who were born between 1978-1994 [37]; and Generation Z, i.e., people born from 1995-2009 [39]. These periods were adopted due to life-changing events that affected Greece and those entering adulthood. 
The research was materialized through a questionnaire developed explicitly for this purpose, based on previous studies and qualitative research with in-depth interviews. The literature review resulted in encompassing in the questionnaire attitudes as well as the economic crisis issue since previous studies had shown that organic food purchasing behaviour is affected by attitudes $[20,21,115]$ and income constrains, either directly or indirectly [116]. The latter is significantly influenced under conditions of fiscal crisis, and it consequently impacts directly on consumers' purchasing power, which decreases substantially in turbulent economies. The qualitative research results of this study confirmed the items encompassed in the questionnaire that referred to consumers' attitude toward organic food and provided the items referring to the economic crisis. This qualitative research was realized through personal interviews, implementing non-probability sampling (i.e., participants were recruited by convenience sample) since probability sampling in qualitative research is not considered to be a necessity [117]. As for data collection in the qualitative research phase, an open-end questionnaire (identical for all subjects) was used, with the participation of five subjects per cohort (i.e., 25 participants). After receiving the subjects' consent, all discussions were recorded digitally [54,118], then transcribed, and results were cross-checked with the items in the questionnaire. Phrases and lexical items employed by subjects' multiple times further developed the items of the economic crisis. For the purpose of the study, researchers created a Facebook account. More precisely, through this account, individuals who participated in the study had access to the results and were asked to review the data analysed and confirm their authenticity [11]. This was feasible for the participants who had access and ease with new technologies. Though, the older participants were presented with a printed hand-out with the results and were asked to confirm the findings. Through this process, member validity was ensured [119]. Next, in order to ensure that the final questionnaire is functional, a small-scale pilot test ( $\mathrm{N}=150$; 30 persons per cohort, excluded from the final research) was undertaken for face validity matters [120]. A non-probability sampling method was used (convenience sampling) via an aided self-administrated questionnaire (in the presence of the researchers in order to pinpoint at first-hand problems encountered). The pilot test led to modifications regarding syntax and grammar, finalizing the questionnaire for the field (i.e., quantitative) research. The quantitative research took place by implementing an online and printed questionnaire and utilizing a non-probability mixed sampling method (convenience and snowball sampling). The data collection method varied based on cohort, access to the internet, and ease with new technologies. Specifically, information from the Gen Z, Y, X cohort as well as the younger subjects of the BB generational cohort was gathered electronically, via the internet (i.e., e-mail and Facebook). Furthermore, a printed questionnaire was used for those without access to the internet, applying a self-administrated or aided self-administrated questionnaire, while for the very elderly $(>70)$ or illiterate, personal interviews were utilized. The link for the online data gathering remained active from April to December 2018. This procedure led to a sample of 1562 usable questionnaires, which were considered appropriate for the statistical analysis since they met the pre-set criteria. It should be pointed out that given the existing economic and time barriers, this method was considered as the most realistic.

The survey was officially approved by the members of the Department of Business Administration of the International Hellenic University with reference number 3/EH $\Delta-31.1 .2018$.

\section{Measures}

Three issues were introduced and thoroughly examined in this research: frequency of purchasing organic food, attitudes toward organic food, and the impact of the economic crisis on purchasing behaviour. As concerns the frequency of purchase, it refers to purchase behaviour (PB) and is the control question, stated as "How often do you purchase organic food?". PB is presented on a seven-point Likert-type scale $(1=$ Never, $2=$ Very rarely, $3=$ Rarely, $4=$ Neither rarely $/$ nor frequently (sometimes/occasionally), $5=$ Frequently, $6=$ Very frequently, and $7=$ Always). Regarding the question referring to the attitudes toward organic food (ATT), six items were adopted from Gil [115], which were the ones confirmed by the qualitative research. These items were organic products are healthier (ATT1); 
organic products are tastier than the conventional ones (ATT2); organic products have superior quality (ATT3); organic products are worse than the conventional ones (reversed- ATT4); organic products do not have harmful effects (ATT5); and organic products are a fraud (reversed-ATT6).

Regarding the questionnaire items referring to the impact of the economic crisis on organic food product behaviour, they stemmed from qualitative research. The items used were EC1: Due to extreme cut-offs in our salaries, it is difficult for us to purchase organic food (EC1); EC2: Even after the crisis and the salary cut-offs, organic farm products, and food are still very expensive (EC2); EC3: After the signing of the Memorandum of Understanding (MOU), I believe that the controls for organic agricultural products and food are incomplete (EC3); EC4: The financial crisis has increased the uncertainty I feel about the quality of the organic food I buy (EC4); EC5: Due to the economic crisis and salary cut-offs, I have to spend wisely my money; I will cover first my house/household expenses and then care for organic food products (EC5). Answers for attitudes and economic crisis effects were rated (excluding the control question) on a $7=$ seven-point Likert scale $(1=$ Completely disagree, $2=$ Disagree, $3=$ Somewhat disagree, $4=$ Neither agree nor disagree, $5=$ Somewhat agree, $6=$ Agree, and $7=$ Completely agree).

The data analysis performed has encompassed descriptive statistics (frequencies, percentages (\%) and mean scores (MS)), in order to respond to the three first objectives of the study (No.1-3/ RQ1-RQ3). Also, it employed reliability analysis and exploratory factor analysis (EFA) with varimax rotation. The latter was used to decrease the variables and provide new ones (constructs-dimensions) for further analysis. Additionally, analysis of variance (ANOVA) was used for the comparison of the subpopulations of the generational cohorts' (objective N.4/RQ4). Lastly, the use of multiple comparisons of means was considered to investigate existing differences between cohorts and organic food behaviour (significance level in all hypothesis testing procedures preset at $\alpha=0.05$ ), answering RQ5 (the fifth objective of the study).

As regards the content validity of the attitude items used in the analysis, these were dependent on the study of Gil [115] from where the specific items were adopted, while in relation to the economic crisis items, content validity was confirmed by two specialists on consumer behavioural economics. Moreover, the Exploratory Factor Analysis (EFA) with varimax rotation of all eleven items produced two constructs, i.e., attitude (ATT) and economic crisis (EC), which were tested for validity. The calculated reliability of each construct was $\alpha=0.903$ and $\alpha=0.870$ for attitudes and economic crises, respectively, while for the total scale, it was $\alpha=0.886$, which is considered adequate [121] for the final research study. Convergent validity for every construct was calculated (Table 2) via average variance extracted (AVE) and composite reliability (CR) using the equation of Fornell and Lacker [122]. The criterion of Fornell and Lacker [122] was also utilized in order to explore discriminant validity, which is recognized when the correlations among the constructs are lower than the square root of the AVE. In Table 2, the first diagonals represent the square root of the AVE, while the other entries represent the correlations, resulting in discriminant validity.

Table 2. Test for convergent and discriminant validity.

\begin{tabular}{ccc}
\hline Behaviour Constructs & $\begin{array}{c}\text { Construct 1 } \\
\text { (Attitudes-ATT) }\end{array}$ & $\begin{array}{c}\text { Construct 2 } \\
\text { (Economic Crisis-EC) }\end{array}$ \\
\hline Construct 1 (ATT; $\mathrm{n}=6)$ & 0.806 & \\
Construct 2 $(\mathrm{EC} ; \mathrm{n}=5)$ & 0.393 & 0.783 \\
AVE & 0.649 & 0.613 \\
CR & 0.917 & 0.888 \\
Cronbach $\alpha$ of construct & 0.903 & 0.870 \\
\hline
\end{tabular}

Source: The authors. AVE: average variance extracted; CR: composite reliability. 


\section{Results and Discussion}

\subsection{Sample Profile}

Females subjects were slightly overrepresented (Table 3), whereas in relation to the generational cohorts, the Silent Generation, Gen X, and Gen Y were underrepresented. As to marital status, about half of the participants were married. Regarding education, about one half of the sample had completed secondary education. Concerning profession, three groups stand out—dependent (i.e., housekeepers, students, and unemployed), employees (both from the private and civil sector), and retired. Lastly, regarding net family monthly income, the majority of the participants can be distinguished into two groups: $\leq € 1000.00$ and the $€ 1000.01-2000.00$ range. It should be pointed out that as regards students, their income was calculated as the amount they receive from their parents, adding any other income they may have (e.g., from a part-time or full-time post).

Table 3. Profile of participants in the field research.

\begin{tabular}{|c|c|c|}
\hline Sample Characteristics & Frequencies & Percentages (\%) \\
\hline \multicolumn{3}{|l|}{ Gender } \\
\hline Male & 739 & 47.3 \\
\hline Female & 823 & 52.7 \\
\hline \multicolumn{3}{|l|}{ Generational Cohort } \\
\hline Silent Generation & 201 & 24.1 \\
\hline Baby Boomers & 314 & 27.4 \\
\hline Generation X & 242 & 15.5 \\
\hline Generation $Y$ & 428 & 20.1 \\
\hline Generation Z & 377 & 12.9 \\
\hline \multicolumn{3}{|l|}{ Marital status } \\
\hline Single & 628 & 40.2 \\
\hline Married & 758 & 48.5 \\
\hline Divorced & 70 & 4.5 \\
\hline Widowed & 106 & 6.8 \\
\hline \multicolumn{3}{|l|}{ Education } \\
\hline Primary & 212 & 13.5 \\
\hline Secondary & 707 & 45.3 \\
\hline Postsecondary & 190 & 12.2 \\
\hline Graduate & 395 & 25.3 \\
\hline Postgraduate & 58 & 3.7 \\
\hline \multicolumn{3}{|l|}{ Profession } \\
\hline Employee (public-private) & 449 & 28.8 \\
\hline Businessman & 274 & 17.6 \\
\hline Worker & 48 & 3.1 \\
\hline Dependent (housekeeper, student, unemployed) & 459 & 29.4 \\
\hline Pensioner & 331 & 21.2 \\
\hline \multicolumn{3}{|l|}{ Area of residence } \\
\hline City & 1033 & 66.1 \\
\hline Town & 240 & 15.4 \\
\hline Village & 289 & 18.5 \\
\hline \multicolumn{3}{|l|}{ Net Monthly Family Income (in euros) } \\
\hline$\leq 350.00$ & 80 & 5.1 \\
\hline $350.01-1000.00$ & 558 & 35.7 \\
\hline $1000.01-2000.00$ & 689 & 44.1 \\
\hline $2000.01-3000.00$ & 182 & 11.7 \\
\hline
\end{tabular}

Source: The authors.

\subsection{Generational Cohort's Organic Purchasing Behaviour}

Regarding the generational cohorts' self-reported purchasing patterns of organic food (first objective of the study), results reveal that overall, the total sample purchases organic food occasionally (MS $=4.52$. . A closer look at the generational cohorts reveals the following. To begin with, the Gen $\mathrm{Z}$ 
cohort has the lowest mean score (MS = 4.19) and purchases organic food sometimes/occasionally; the same applies to the Gen $Y$ cohort (MS = 4.35). On the other hand, the older generations tend to purchase organic food more frequently. For example, the Silent Gen has the highest mean score (MS $=4.96$ ), which approaches the "frequently" category, with Gen X being the second in order with MS $=4.80$. Baby Boomers exhibit a MS $=4.68$ mean score, revealing a tendency toward the frequent purchase of organic food. One should highlight that no generational cohort has MS > 5.00, and, therefore, no cohort purchases organic food frequently, very frequently, or always.

Previous research on generational cohorts and organic food purchasing behaviour reveals that as regards the Gen $\mathrm{Z}$ cohort, the results of this study are aligned with previous studies [11]. Kamenidou et al. [11] found that Gen Z university students are not following an SFC behaviour, maybe due to convenience, taste, time, price, or accessibility to junk food $[123,124]$. As regards Gen Y (or the so-called millennials), which is the most explored generational cohort regarding OFB, previous studies demonstrate that they have keenly adopted green food [125], are willing to pay more for organic food [113], and, overall, they are more responsible consumers [126]. However, the present study contradicts the above findings since it shows that Gen Y'ers occasionally purchase organic food. It has also become evident through our findings that the older generations (i.e., Silent Gen, Baby Boomers, Gen X) are the ones that are more heavily engaged in actual organic food purchase behaviour. The latter cannot be directly compared with results from other studies since the above parameters had not been previously explored for these cohorts. Though, this study can be compared to and considered in alignment with the study of Wandel and Bugge [127], which reported that older consumers purchase organic food being motivated by their own health considerations.

\subsection{Factor Analysis-Variable Reduction}

Exploratory Factor Analysis (EFA) with varimax rotation was applied to the eleven items rated on the OFB scale (excluding the control question) in order to investigate the constructs derived. EFA produced two distinctive constructs (Eigen values $>1$ ). The first factor is named "attitude toward organic food" (ATT), and the second is called the "economic crisis" (EC). Both constructs explain $67.0 \%$ of the total variance, with the total reliability of the scale being $\alpha=0.886$. Table 4 presents the results of EFA, and for each factor, its name, the total variance explained (TVE), its reliability, its mean factor score (MFS), and the loading of each item per factor.

Table 4. Results factor analysis and organic food statements.

\begin{tabular}{|c|c|c|}
\hline \multirow{2}{*}{ Constructs/Dimensions \& Items/Construct } & \multicolumn{2}{|c|}{ Loading on Factor } \\
\hline & 1 & 2 \\
\hline \multicolumn{3}{|l|}{$\begin{array}{l}\text { First construct: attitude toward organic food (ATT) TVE }=36.8 \% \alpha=0.903 \\
\qquad \text { MFS }=4.42(\text { Std }=1.25)\end{array}$} \\
\hline Organic products are healthier (ATT1) & 0.795 & \\
\hline Organic products are tastier than the conventional ones (ATT2) & 0.807 & \\
\hline Organic products have superior quality (ATT3) & 0.730 & \\
\hline Organic products are worse than the conventional ones ${ }^{\circledR}$ (ATT4) & 0.843 & \\
\hline Organic products do not have harmful effects (ATT6) & 0.832 & \\
\hline Organic products are a fraud ${ }^{\circledR}($ ATT7) & 0.822 & \\
\hline \multicolumn{3}{|c|}{ Second construct: economic crisis $(\mathrm{EC}) \mathrm{TVE}=30.2 \% \alpha=0.870 \mathrm{MFS}=4.62(\mathrm{Std}=1.31)$} \\
\hline Due to extreme cut-offs in our salaries, it is difficult for us to purchase organic food (EC1) & & 0.764 \\
\hline $\begin{array}{c}\text { Even after the crisis and the salary cut-offs, organic farm products and food are still very } \\
\text { expensive (EC2) }\end{array}$ & & 0.785 \\
\hline $\begin{array}{l}\text { After the signing of the Memorandum of Understanding (MOU), I believe that the controls } \\
\text { for organic agricultural products and food are incomplete (EC3) }\end{array}$ & & 0.824 \\
\hline $\begin{array}{l}\text { The financial crisis has increased the uncertainty I feel about the quality of the organic } \\
\text { food I buy (EC4) }\end{array}$ & & 0.842 \\
\hline $\begin{array}{l}\text { Due to the economic crisis and salary cut-offs, I have to spend wisely my money; I will } \\
\text { cover first my house/household expenses and then care for organic food products (EC6) }\end{array}$ & & 0.755 \\
\hline
\end{tabular}

Source: the authors. 
The Mean Factor Score (MFS) of each of the two dimensions-constructs extracted from factor analysis were used as new variables in the ANOVA model procedure in order to investigate whether differences exist between generational cohorts and organic food behaviour.

\subsection{Attitudes toward Organic Food}

Taking the first construct into account, and aiming at more in-depth analysis, attitudes toward organic food per generational cohort as well as for the total sample in Mean Score (MS) are presented in Table 5 (second objective of the study). Answers were rated on a seven-point Likert scale, from $1=$ Completely disagree up to $7=$ Completely agree.

Table 5. Attitudes toward organic food per cohort and in total (MS).

\begin{tabular}{|c|c|c|c|c|c|c|}
\hline Attitude & $\begin{array}{c}\text { Gen Z } \\
N=377\end{array}$ & $\begin{array}{c}\text { Gen } Y \\
N=428\end{array}$ & $\begin{array}{c}\text { Gen X } \\
N=242\end{array}$ & $\begin{array}{c}\text { BB } \\
N=314\end{array}$ & $\begin{array}{c}S G \\
N=201\end{array}$ & $\begin{array}{l}\text { Total Sample } \\
\quad N=1562\end{array}$ \\
\hline $\begin{array}{l}\text { Organic products are } \\
\text { healthier (ATT1) }\end{array}$ & 4.81 & 5.21 & 5.72 & 5.39 & 5.43 & 5.26 \\
\hline $\begin{array}{l}\text { Organic products are tastier } \\
\text { than the conventional ones } \\
\text { (ATT2) }\end{array}$ & 5.35 & 5.51 & 5.98 & 5.55 & 5.50 & 5.55 \\
\hline $\begin{array}{l}\text { Organic products have } \\
\text { superior quality (ATT3) }\end{array}$ & 4.78 & 5.03 & 5.58 & 5.36 & 5.39 & 5.17 \\
\hline $\begin{array}{c}\text { Organic products are worse } \\
\text { than the conventional } \\
\text { ones }^{\circledR} \text { (ATT4) }\end{array}$ & 4.91 & 5.29 & 5.49 & 5.37 & 5.15 & 5.22 \\
\hline $\begin{array}{c}\text { Organic products do not } \\
\text { have harmful effects (ATT5) }\end{array}$ & 4.99 & 5.31 & 5.45 & 5.25 & 5.02 & 5.20 \\
\hline $\begin{array}{l}\text { Organic products are a } \\
\text { fraud }^{\circledR}(\text { ATT6) }\end{array}$ & 4.96 & 5.25 & 5.58 & 5.39 & 4.97 & 5.22 \\
\hline
\end{tabular}

Source: The authors.

Table 5 displays that, as concerns attitudes toward organic food, no mean score is $\geq 6.00$, nor $\leq 4.50$. Therefore, cohorts' attitudes are considered positive since all the mean scores range from 4.78-5.98, implying that participants somewhat agree or tend to agree with the above statements. Table 6 also reveals that the most positive attitudes come from Gen X, for the statement, "Organic products are tastier than the conventional ones". Furthermore, the least favourable attitudes are derived from the Gen $Z$ cohort, and toward the statement, "Organic products have superior quality". Concerning the total sample, the statement with the higher rating is also "Organic products are tastier than the conventional ones", while the statement, "Organic products have superior quality" has the lowest rating.

Generally, people who adopt a positive attitude toward organic food are inclined to proceed to organic purchasing behaviour. This behaviour is demonstrated in previous studies [91,128]; yet, Magnusson et al. [116] in their study found that - even though consumers had an overall positive attitude toward organic food- their purchasing behaviour was low. The results of our study reveal that all generational cohorts tend to have favourable attitudes toward organic food since, in all cases MS $>4.70$. A closer look at the actual purchasing behaviour per generational cohort has revealed that the results are partially along the lines of Magnusson et al.'s [116] study. Magnusson et al. [116] found that while consumers exhibited positive attitudes toward organic food, the older customers were the ones that were more prone to purchasing them. 


\subsection{Economic Crisis Influence and Organic Food}

In the current study, the construct of the economic crisis was analyzed further and in-depth per each generational cohort (third objective of the study). The following table (Table 6) presents the influence the economic crisis has on consumers' attitudes and behaviour toward organic food per generational cohort as well as for the total sample in Mean Score (MS). Answers were rated on a seven-point Likert scale, from $1=$ Completely disagree up to $7=$ Completely agree.

Table 6. Economic crisis and OFB per cohort and in total (MS).

\begin{tabular}{|c|c|c|c|c|c|c|}
\hline Economic Crisis & $\begin{array}{c}\text { Gen } \mathrm{Z} \\
\mathbf{N}=377\end{array}$ & $\begin{array}{c}\text { Gen } Y \\
N=428\end{array}$ & $\begin{array}{c}\text { Gen X } \\
N=242\end{array}$ & $\begin{array}{c}\text { BB } \\
N=314\end{array}$ & $\begin{array}{c}S G \\
N=201\end{array}$ & $\begin{array}{c}\text { Total Sample } \\
\quad \mathrm{N}=1562\end{array}$ \\
\hline $\begin{array}{l}\text { Due to extreme cut-offs in } \\
\text { our salaries, it is difficult for } \\
\text { us to purchase organic food } \\
\text { (EC1) }\end{array}$ & 3.97 & 4.26 & 4.50 & 4.71 & 4.63 & 4.36 \\
\hline $\begin{array}{l}\text { Even after the crisis and the } \\
\text { salary cut-offs, organic farm } \\
\text { products and food are still } \\
\text { very expensive (EC2) }\end{array}$ & 3.99 & 4.13 & 4.50 & 4.57 & 4.74 & 4.32 \\
\hline $\begin{array}{l}\text { After the signing of the } \\
\text { Memorandum of } \\
\text { Understanding (MOU), } \\
\text { I believe that the controls } \\
\text { for organic agricultural } \\
\text { products and food are } \\
\text { incomplete (EC3) }\end{array}$ & 4.76 & 4.86 & 4.97 & 4.97 & 4.80 & 4.86 \\
\hline $\begin{array}{l}\text { The financial crisis has } \\
\text { increased the uncertainty I } \\
\text { feel about the quality of the } \\
\text { organic food I buy (EC4) }\end{array}$ & 4.69 & 4.86 & 4.99 & 4.86 & 4.55 & 4.80 \\
\hline $\begin{array}{l}\text { Due to the economic crisis } \\
\text { and salary cutoffs, I have to } \\
\text { spend wisely my money; } \\
\text { I will cover first my } \\
\text { house/household expenses } \\
\text { and then care for organic } \\
\text { food products (EC5) }\end{array}$ & 4.52 & 4.82 & 4.98 & 4.87 & 4.49 & 4.74 \\
\hline
\end{tabular}

The first conclusion drawn based on Table 6 is that mean scores range from $3.9 \geq \mathrm{MS} \leq 5.00$ for all cases and for the total sample and generational cohorts too. This indicates that overall, participants tend to agree with the above statements since only six mean scores are $3.9<\mathrm{MS}<4.50$, while the rest range between 4.51-4.99. An observation of the results also implies that the youngest generational cohort is the one least affected by the crisis as it refers to OFB, even though it is the cohort that has experienced the consequences coming from it. Additionally, the following points are also noticeable. In relation to ease of purchase of organic food due to cut-offs, the BB cohort is the one most affected, while the Gen $Z$ cohort is the least. As refers to whether organic food products are perceived to have high prices in the turbulent economic condition of the country, results show that passing from the younger cohorts to the older ones, this perception strengthens. Additionally, cohorts express disbelief and uncertainty toward the quality controls implemented by the government and, consequently, the quality of organic products. Finally, all cohorts point out that they have become more rational in spending their household income, covering at first the necessities of their household, and then consider organic food choices.

Under conditions of financial crises, prior studies seem to confirm that consumers adjust their purchase and consumption behaviour accordingly. People become more rational consumers as they 
purchase only the necessary goods, reducing extra purchases, and they shift to cheaper substitutes of expensive material or products in order to satisfy their needs [129]. In the food product context, Basen [58] asserts that research associated with consumers' food purchasing behaviour within the fiscal crisis has not been thoroughly studied, and consequently, the issue needs further investigation. Regarding economic crisis and food security issues in Greece, Kamenidou et al. [26] found that $65.6 \%$ of the sample ( $\mathrm{N}=1305$ households) answered that they agree or strongly agree that the economic crisis has had an impact on food access, forcing them to take proactive actions against future food insecurity. With the focus on organic food, preceding studies mention that income does influence their purchase behaviour, as organic food products are sold at higher prices in the marketplace, which has been pinpointed by researchers as one of the greatest barriers against consumers' organic food purchase [116]. Both income and price trigger affordability issues [92], with the latter playing a significant role in consumers' purchase intentions toward organic food and its products [130]. For example, Pham et al. [131] found that with respect to organic food, affordability issues do exist for young Vietnamese consumers since organic food has a high cost, which in turn prevented purchase. Similarly, the findings of other researches have made evident the positive relation that stands between income and organic product purchase, and vice versa [132,133]. During the 11-year economic crisis that has severely affected the country, Greeks have faced excessive cut-offs in their income, they have been heavily taxed, and their purchasing power condensed dramatically [134]. This, in turn, has prohibited people from purchasing organic food due to their higher price compared to conventional food [22]. Specifically, Lodorfos et al. [135] asserted that, as regards organic food and drinks in Europe, the economic crisis has led to a decline in demand for these products due to the decreased consumer spending power.

The findings of our study confirm the afore-mentioned findings, though they contradict the results of Krystallis and Chryssohoidis [136], who claim that younger consumers are more willing to pay more and purchase bigger quantities of organic food due to being environmentally conscious. The findings of Krystallis and Chryssohoidis [136], which are associated with the same country where this study is realized, are retrieved before the fiscal crisis, and as such, they are compared with cautiousness. A more recent study referring to Greece, though, which was not exclusively focused on organic food [137], found that the economic crisis in Greece has a direct negative impact on food consumption. Our study's findings are also in line with the findings of Aguirre Gonzalez [24], who found that the world crisis of 2007-2008 had affected both consumption and willingness to pay for organic food products. Similar to them, Amvrosiou et al. [22], while exploring the Greek ongoing economic crisis, concluded that the crisis affected the organic food consumption negatively, due to consumers' high price sensitivity. As for the interplay between generational cohorts and economic crisis, Casini et al. [138] suggested that as regards the Gen X cohort, there is a per capita food spending reduction, which partially worsened by the economic crisis. One reason justifying this behaviour could be Gen Xs' support toward their children in different ways: preparing them (with extra and out of school tutoring) for the PanHellenic university exams; taking care of their children's' expenses if they are already studying and residing away from home, supporting them financially in the case that their children are unemployed, and supporting them in the case of being married, resulting thus in having extra expenses.

Regarding distrust of quality control as a result of the economic crisis, prior research has shown that consumers have expressed distrust for food as being organic, even in non-crisis situations [139]. On the other hand, Janssen and Hamm [140] found that consumers do pay attention to certification labels when they purchase organic products and have low levels of trust concerning unpopular ones.

\subsection{Generational Cohort Differences in Organic Food Behaviour}

In order to define whether there are differences between generational cohorts and their purchasing behaviour (PB), their attitude toward organic food (ATT), and the effect of the economic crisis (EC) on their behaviour (objective No.4 of the study/ RQ4), three hypotheses were formulated. The first hypothesis is defined as: 
Hypothesis 1 (H1). There are differences between generational cohorts in terms of the frequency of purchasing organic food. This hypothesis is presented statistically as:

Hypothesis 1a (H1a). There are no statistically significant differences between the generational cohorts and their purchasing behaviour of organic food $(a=0.05)$.

Hypothesis $\mathbf{1 b}(\mathbf{H 1 b})$. There are statistically significant differences between the generational cohorts and their purchasing behaviour of organic food $(a=0.05)$.

The second hypothesis derived from the RQ4 follows below:

Hypothesis 2 (H2). There are differences between generational cohorts in terms of attitude toward organic food. This hypothesis is presented statistically as:

Hypothesis 2a (H2a). There are no statistically significant differences between the generational cohorts and their attitude toward organic food $(a=0.05)$.

Hypothesis $\mathbf{2 b}(\mathbf{H} 2 \mathbf{b})$. There are statistically significant differences between the generational cohorts and their attitude toward organic food $(a=0.05)$.

Finally, the third hypothesis that derived from RQ4 is

Hypothesis 3 (H3). There are differences between generational cohorts in terms of the impact of the economic crisis and purchasing of organic food, which is presented as follows:

Hypothesis 3a (H3a). There are no statistically significant differences between the generational cohorts and the impact of the economic crisis on purchasing organic food $(\mathrm{a}=0.05)$.

Hypothesis $3 \mathbf{b}(\mathbf{H} 3 \mathbf{b})$. There are statistically significant differences between the generational cohorts and the impact of the economic crisis on purchasing organic food $(a=0.05)$.

In order to examine the three hypotheses stemming from RQ4, differences in frequency of purchasing, attitude, and impact of the economic crisis on purchasing organic food were compared among generational cohort groups implementing One-Way ANOVA tests. More precisely, Table 7 presents the outcome of One-Way ANOVA tests for the above three hypotheses. In the ANOVA model, the generational cohort and its subgroups form the independent variable, while the frequency of purchasing (based on MS), attitude, and impact of the economic crisis on purchasing organic food constitute the dependent variables (based on the MFS of dimensions derived). The ANOVA results revealed that in all cases, all dimensions differed significantly between cohorts (Table 7).

Table 7. ANOVA tests between organic food behaviour and generational cohorts.

\begin{tabular}{ccccccc}
\hline & & $\begin{array}{c}\text { Sum of } \\
\text { Squares }\end{array}$ & df & $\begin{array}{c}\text { Mean } \\
\text { Square }\end{array}$ & F & Sig. \\
\hline \multirow{2}{*}{$\begin{array}{c}\text { Purchasing } \\
\text { Behaviour }\end{array}$} & Between Groups & 118.335 & 4 & 29.584 & & \\
& Within Groups & 3234.966 & 1556 & 2.079 & 14.230 & 0.000 \\
& Total & 3353.300 & 1560 & & & \\
\hline \multirow{2}{*}{ Attitude } & Between Groups & 89.336 & 4 & 22.334 & & \\
& Within Groups & 2325.561 & 1556 & 1.495 & 14.943 & 0.000 \\
& Total & 2414.897 & 1560 & & & \\
\hline \multirow{2}{*}{ Economic } & Between Groups & 37.696 & 4 & 9.424 & & \\
Crisis & Within Groups & 2650.318 & 1556 & 1.703 & 5.533 & 0.000 \\
& Total & 2688.014 & 1560 & & & \\
\hline
\end{tabular}


Concerning the first hypothesis-i.e., the control question referring to the frequency of purchasing organic food-the One-Way ANOVA test revealed significant differences between generational cohorts $(\mathrm{F}(4.1556)=14.230, p<0.001)$. Thus, the null hypothesis is rejected. Also, referring to attitudes toward organic food (second hypothesis), the One-Way ANOVA test also unveiled significant differences between generational cohorts $(\mathrm{F}(4.1556)=14.943, p<0.001)$. Hence, the null hypothesis is rejected in this case, as well. Lastly, for the effect of the economic crisis on purchasing behaviour (i.e., third hypothesis), One-Way ANOVA also showed significant differences between generational cohorts $(\mathrm{F}(4.1556)=5.533, p<0.001)$. As a result, the null hypothesis is also rejected.

Therefore, the results of this study clearly show that in all cases, at least two cohorts differ in their purchasing behaviour, their attitude toward organic food, and the impact the economic crisis has on the purchase of organic food.

\subsection{Multiple Comparison of Means}

In order to investigate in detail, the results of the One-Way ANOVA, multiple comparisons of means were conducted in an attempt to pinpoint which generational cohorts differ amongst others (fifth objective of this paper/RQ5). To be more precise, the significant difference comparisons in the generational cohorts' ratings for the control question and the two dimensions extracted from EFA, were performed using the post hoc Scheffe comparisons measures (Table 8). Table 8 depicts the results of the post-hoc Scheffe tests. The $a, b, c$ letters reveal for each mean score if it is significantly different from others. Thus, in each row, mean scores with different letters are significantly different. This indicates that in the same row, cohorts with the same letter per mean score in the row have similar behaviour, while with different letters, the cohort differentiates its behaviour from the other cohorts (for the specific variable tested). For all cases, the letter " $a$ " is the starting point and carries the highest mean score per row.

Table 8. Scheffe test between organic food behaviour and generational cohorts.

\begin{tabular}{cccccc}
\hline $\begin{array}{c}\text { Control Question \& } \\
\text { Dimensions }\end{array}$ & Gen Z & Gen Y & Gen X & Baby Boomers & $\begin{array}{c}\text { Silent } \\
\text { Generation }\end{array}$ \\
\hline Purchasing & $4.19 \mathrm{c}$ & $4.35 \mathrm{bc}$ & $4.80 \mathrm{a}$ & $4.68 \mathrm{ab}$ & $4.96 \mathrm{a}$ \\
Behaviour & $4.11 \mathrm{~b}$ & $4.27 \mathrm{~b}$ & $4.61 \mathrm{a}$ & $4.67 \mathrm{a}$ & $4.70 \mathrm{a}$ \\
Attitude & $4.39 \mathrm{~b}$ & $4.59 \mathrm{ab}$ & $4.79 \mathrm{a}$ & $4.80 \mathrm{a}$ & $4.64 \mathrm{ab}$ \\
\hline Economic Crisis & & & & \\
\hline
\end{tabular}

The results from Table 8 disclose that in relation to the frequency of purchasing organic food, Scheffe's test indicated that the mean scores for the older cohorts are significantly higher compared to the younger ones' with the Silent Gen, the Baby Boomers and Gen X purchasing more frequently organic food compared to Gen Z and Gen Y.

One reason that could justify the low organic food purchase rate for Gen $Z$ compared to the other cohorts could be that they live with their families and, thus, they are not the ones that do or decide on the purchase of food and goods. Another reason could be that they study at a "reasonable distance" from their parents' residence. Hence, even though they live by themselves, they become recipients of regular food packages from their families. Family support in this manner has as a result that they do not frequently engage in food purchasing. In terms of cultural-specific norms, it is in the Greek mentality that, when a university student lives in a city that is of near proximity to their permanent residence, his or her parents will cook meals for even a whole week and give or send the package to their children so that they can engage in their studies without having to think about food issues or cooking. This could be a reason why Gen Z presents a low-frequency rate of organic food purchase.

Finally, a third reason that this could be attributed to is that younger people usually do not suffer from health problems, and as such, they do not engage in improved nutrition patterns. Previous research [141] claims that married and older people have a greener purchasing behaviour as opposed 
to young and single participants. Moreover, Tripathi [142], firmly asserts that individuals tend to be more health-conscious by aging. The rationale of non-existing health issues could also justify why this cohort displays the least favourable attitude toward organic food.

As regards the dimension "attitude toward organic food", Scheffe's test suggests that the mean score for the older cohorts is significantly higher than that for the younger ones. Thus, passing from the younger generational cohort to the older ones, the attitude expressed toward organic food becomes more favourable. This behaviour is also supported by previous authors [141,142].

Lastly, referring to the dimension "Economic Crisis", Scheffe's test suggests that the mean score for the Baby Boomers and Gen X is significantly higher than the other generational cohorts. It also reveals that these participants have been affected mostly by the economic crisis, while the younger generational cohorts (Gen Z and Gen Y) have been less influenced.

As for Gen Z, being less affected by the economic crisis could be derived from the fact that they are still under the "protection" of their parents, and for so, their parents still take care of their expenses. On the other hand, Gen Y members could be less affected possibly for two reasons; first, they still live with their parents-especially if they are single—or they live on their own and have a job so that they can bear their own expenses. Second, if they are married and have children, it is again part of Greek culture that parents and parents-in-law support them either by bringing them cooked homemade meals and taking care of their children, or by providing them with a part of their income in order to help their children during times of economic constraints.

\section{Conclusions-Implementation}

This study aimed to explore organic food behaviour among multiple generational cohorts, looking for generational differences in behaviour. Six objectives were defined which were subsequently examined. For this to be feasible, a multi-research approach was applied, exploring the behaviour of five generational cohorts, i.e., the Silent Generation, the Baby Boomers, Generation X, Generation Y, and Generation $Z$ (the youngest adult generation). Five of the six objectives refer directly to the data, while the sixth refers to the recommendations for policymakers and marketing communication actions.

The first objective of the study relates to the cohorts' organic food purchasing behaviour. Analysis showed that as regards the total sample, purchase of organic food products is not systematic and is realized on occasional basis. Additionally, it reveals that the Gen $\mathrm{Z}$ cohort presents the lowest purchasing behaviour and the Silent Gen cohort the highest one. The second objective of the study was to investigate the attitudes that each generational cohort holds toward organic food. Analysis identified that cohorts have or tend to have positive attitudes toward organic food. The third objective dealt with the effect of the economic crisis on OFB and uncovered that it has a direct impact on attitude and purchase behaviour due to distrust of quality. The fourth and fifth objective tackled, associates with differences in generational cohort behaviour regarding OFB and focuses specifically on attitudes, effect of the economic crisis, and purchase behaviour. The ANOVA results revealed that in all cases, differences exist between generational cohorts and $\mathrm{OFB}$, while further analysis via multiple comparison of means, uncovered the specific differences between cohorts. Lastly, the sixth objective of the study is associated with actions and marketing communication techniques by policymakers to promote SFB and OFB. This objective is achieved via the following.

Academics point out that changes in food consumption behaviour are challenging and require well planned and executed social marketing programs to influence targeted audiences to voluntarily modify a behaviour in order to increase the well-being of individuals and/or society [143]. Power ([144] p. 1), stresses that "changing behaviour is notoriously challenging, and changing food habits is particularly difficult, partly because food tends to be such an emotive issue, bound up with cultural and personal perceptions". This is particularly true since food does not satisfy only physiological need but is also related to social, cultural, aesthetic, symbolic, moral, health, environmentally conscious, or religious beliefs [145]. 
As for practical applications, the findings of the present study could lead the actions of government policymakers in order to promote SFC and OFB under economic crisis conditions. National policies in Greece may focus on informing consumers, and especially, the younger ones about the health and environmental benefits of organic food [146] and also on setting solid ground for establishing their credibility $[147,148]$. Lack of trust on organic food authenticity is a major factor negatively influencing consumer behaviour [149]. Especially in Greece, during the period of economic crisis, mistrust in authorities exists in general [26]. Since consumers in the vast majority do not have the skills and knowledge to distinguish organic food, it has to be credible so that consumers can trust the product in order to purchase it [149]. Therefore, it is very important that consumers perceive that control systems and logos labelling organic food as credible and with strict procedures, since trust is generally acknowledged in the academic research as a factor that enables to buy organic food products [147].

The solution of certification is an obvious but not adequate solution to the credibility issues Close monitoring should be adopted for the suppliers of organic food to separate and penalise dishonest suppliers and/or retailers [148]. The credence characteristics of organic products may constitute the most important dimension of communication to consumers. An operational certification and labelling system are imperative for establishing successful communication with consumers [150]. The certifying authority must be credible so the consumer to be confident that when buying organic food, the production procedure secured its environmental and health advantages.

Magnusson et al. [116] supported that consumer's concern for own health is more important than environmental concerns and that "that egoistic motives seem to be very strong." In this context, and regarding marketing communication actions, informational campaigns for organic food should stress the benefits for the individual's health and in a second level, focus on the advantages for the society [146].

Current research in consumer psychology related to green products consumption shows that perceptions regarding the nutritional value and naturality of these products (i.e., egoistic buying considerations) along with altruistic considerations (beliefs that organic food is less harmful to the environment) form more powerful communication messages to address the targeted consumers [151].

The results of the current research report the necessity to educate consumers from an early age, targeting thus the generation Alpha cohort, born 2010 and after [152], being the new future generational cohort. Thus, in order to promote the organic food sector, the government must employ consumer education and information programs. These national strategies may include school education in order to develop awareness among children about food, its production and processing and to inform youngsters how to make healthy and sustainable food choices. These educational programs are important in moulding children's and teenagers' future attitudes and concerns about the environment $[153,154]$. Additionally, other reforms that could be introduced are gardening of organic vegetables in school premises and modifications in-school meals offered.

Moreover, previous research shows that Gen X and Gen Y cohort members are generally environmentally aware and voice concerns about society, also having a better understanding of health problems in their communities [155,156]. Marketing communication efforts targeted to Greek consumers should especially raise these key elements since Greeks Gen X and Y members seem more reluctant to buy organic food; that way, they would be fully informed of the important health benefits for themselves but also for the members of their families. Members of the Gen Y cohort have now started creating their own families and have small children, so the importance of having food that is pesticide-free and clear of other chemicals is crucial to them.

Marketing communication for organic food consumption is a very important topic and need to be taken into account for promoting an SFC behaviour. Advertising and communication, in general, play a very significant role in the evaluation of food products [157]. In terms of augmenting the sales of organic food through marketing and communication programs, relevant research has demonstrated that individuals consume more organic food when the benefits are already known to them [158]. Within that context, Beltran [155] suggested that better knowledge could improve understanding of the 
organic food attributes and their benefits, and it could accelerate consumption. This could be facilitated through effective advertising that will combine both textual and visual elements in a complementary way, pointing out specific elements that can lead to a positive influence on how individuals perceive organic food overall [151,157].

Digital campaigns, including social media should be implemented to especially target the younger cohort groups both through educational but also with creative and recreational videos, and the formation of groups that support and promote discussion about organic food consumption and healthier living. While new technologies are used for the young cohorts, social and mass media (TV, Radio) ought to be used in targeting the older consumer cohorts too. Finally, educational events, celebrity endorsement and expert opinion should be applied [131] targeting with different signals different cohorts.

Finally, as regards the topic of this study, earlier studies have advanced our knowledge of sustainable food consumption from various points of view, yet, this study has significant features that diversify it from all the others, with the most important being that it targets simultaneously five different cohorts of a country, therefore providing insights from a sample that covers approximately the total adult age range of the Greek population. Thus, a strong understanding of SFC with a focus on OFB based on five generational cohorts reveals tendencies of the country's sustainable future. From a theoretical perspective, our research paper adds to the existing literature by offering empirical evidence from multigenerational cohorts, where a dearth of studies from a marketing perspective can be accessed. Therefore, it contributes to the literature on two levels-(i) on organic food and sustainability and (ii) on generational cohort research.

\section{Limitations of the Study and Directions for Further Research}

The present research entails certain limitations, some of which may function as points that will trigger future research attempts. Limitations are mainly associated with the sampling method used for data collection. Due to time and resource constraints, a non-probability sampling method has been applied, inevitably leading to reduced generalizability of the study outcomes. A different weakness is closely interwoven with the specific items selected for measuring OFB. The six items which were used for attitudes, although derived from a previous study, were the ones that were confirmed by the qualitative research employed. Even more, the qualitative research provided with the five items measuring the effect of the economic crisis on OFB. Undoubtedly, additional items could have been included in examining the issue of OFB. More expanded and, thus, more representative, research populations could strengthen and lead to even more robust future research, which would also encompass additional variables that may prove also to have some impact on OFB.

Nevertheless, even though this research study demonstrates the above limitations, it is considered of great importance, since it provides insight into the OFB for a plethora of generational cohorts. It also includes the two "extremes" of the cohorts, i.e., the Gen Z cohort as the youngest adults and future mainstream of consumers, and the Silent Gen, as the oldest one, who has directly or indirectly educated the younger generational cohorts with their consumption and purchase behaviour.

Author Contributions: Conceptualization of research and design, I.K.; Formal analysis, I.K. and A.S.; Investigation, I.K.; A.S., and E.-Z.B.; Methodology, I.K., and A.S.; Project administration, I.K. and A.S.; Writing-original draft, I.K.; A.S.; and E.-Z.B.; Writing-review and editing, I.K.; A.S.; and E.-Z.B. All authors have read and agreed to the published version of the manuscript.

Funding: This research received no external funding.

Acknowledgments: We would like to thank the reviewers for their constructive comments, which substantially improved this paper.

Conflicts of Interest: The authors declare no conflict of interest. 


\section{References}

1. Martin, M.; Brandão, M. Evaluating the environmental consequences of Swedish food consumption and dietary choices. Sustainability 2017, 9, 2227. [CrossRef]

2. Shwom, R.; Lorenzen, J.A. Changing household consumption to address climate change: Social scientific insights and challenges. Wiley Interdiscip. Rev. Clim. Chang. 2012, 3, 379-395. [CrossRef]

3. Carlsson-Kanyama, A.; González, A.D. Potential contributions of food consumption patterns to climate change. Am. J. Clin. Nutr. 2009, 89, 1704S-1709S. [CrossRef]

4. Van Dooren, C.; Marinussen, M.; Blonk, H.; Aiking, H.; Vellinga, P. Exploring dietary guidelines based on ecological and nutritional values: A comparison of six dietary patterns. Food Policy 2014, 44, 36-46. [CrossRef]

5. Trudel, R. Sustainable consumer behavior. Consum. Psychol. Rev. 2019, 2, 85-96. [CrossRef]

6. Kotler, P.; Keller, K. Marketing Management, 14th ed.; Pearson Education: London, UK, 2006.

7. Reisch, L.; Eberle, U.; Lorek, S. Sustainable food consumption: An overview of contemporary issues and policies. Sustain. Sci. Pract. Policy 2013, 9, 7-25. [CrossRef]

8. Smith, P.; Gregory, P.J. Climate change and sustainable food production. Proc. Nutr. Soc. 2013, 72, $21-28$. [CrossRef]

9. Collins, A.; Fairchild, R. Sustainable food consumption at a sub-national level: An ecological foot print, nutritional and economic analysis. J. Environ. Policy Plan. 2007, 9, 5-30. [CrossRef]

10. Laureti, T.; Benedetti, I. Exploring pro-environmental food purchasing behaviour: An empirical analysis of Italian consumers. J. Clean. Prod. 2018, 172, 3367-3378. [CrossRef]

11. Kamenidou, I.C.; Mamalis, S.A.; Pavlidis, S.; Bara, E.Z.G. Segmenting the Generation Z Cohort University Students Based on Sustainable Food Consumption Behavior: A Preliminary Study. Sustainability 2019, 11, 837. [CrossRef]

12. Clonan, A.; Wilson, P.; Swift, J.A.; Leibovici, D.G.; Holdsworth, M. Red and processed meat consumption and purchasing behaviours and attitudes: Impacts for human health, animal welfare and environmental sustainability. Public Health Nutr. 2015, 18, 2446-2456. [CrossRef]

13. Tobler, C.; Visschers, V.H.; Siegrist, M. Eating green. Consumers' willingness to adopt ecological food consumption behaviors. Appetite 2011, 57, 674-682. [CrossRef]

14. Vermeir, I.; Verbeke, W. Sustainable food consumption: Exploring the consumer attitude-Behaviour gap. J. Agric. Environ. Ethics 2006, 19, 169-194. [CrossRef]

15. Thøgersen, J. Country differences in sustainable consumption: The case of organic food. J. Macromark. 2010, 30, 171-185.

16. Grubor, A.; Đokić, N.; Milićević, N. Serbian organic food consumer profile: Contradictions of previous researches and methodological possibilities. Škola Biznisa 2018, 1, 123-130. [CrossRef]

17. Baudry, J.; Touvier, M.; Allès, B.; Péneau, S.; Méjean, C.; Galan, P.; Hercberg, S.; Lairon, D.; Kesse-Guyot, E. Typology of eaters based on conventional and organic food consumption: Results from the NutriNet-Santé cohort study. Br. J. Nutr. 2016, 116, 700-709. [CrossRef]

18. Prakash, G.; Singh, P.K.; Yadav, R. Application of consumer style inventory (CSI) to predict young Indian consumer's intention to purchase organic food products. Food Qual. Prefer. 2018, 68, 90-97. [CrossRef]

19. Wojciechowska-Solis, J.; Soroka, A. Motives and barriers of organic food demand among Polish consumers: A profile of the purchasers. Br. Food J. 2017, 119, 2040-2048. [CrossRef]

20. Zagata, L. Consumers' beliefs and behavioural intentions towards organic food. Evidence from the Czech Republic. Appetite 2012, 59, 81-89. [CrossRef]

21. Torjusen, H.; Lieblein, G.; Wandel, M.; Francis, C.A. Food system orientation and quality perception among consumers and producers of organic food in Hedmark County, Norway. Food Qual. Prefer. 2001, 12, $207-216$. [CrossRef]

22. Amvrosiou, A.; Theodoropoulou, E.; Mitoula, R. The Study of the Attitudes and Perceptions of Modern Greeks during the Economic Crisis on the Consumption of Organic Products. Int. Rev. Soc. Sci. 2017, 5, 625-635.

23. Bonaccio, M.; Bes-Rastrollo, M.; De Gaetano, G.; Iacoviello, L. Challenges to the Mediterranean diet at a time of economic crisis. Nutr. Metab. Cardiovasc. Dis. 2016, 26, 1057-1063. [CrossRef] [PubMed] 
24. Aguirre Gonzalez, J.A. World economic crisis impact on organic products consumption: Costa Rica, 2009. Br. Food J. 2012, 114, 5-18. [CrossRef]

25. Schaack, D.; Lernoud, J.; Schlatter, B.; Willer, H.; The Organic Market in Europe 2012 n: Research Institute of Organic Agriculture (FiBL); International Federation of Organic Agriculture Movements (IFOAM) (Eds.) The World of Organic Agriculture. Statistics and Emerging Trends; FiBL: Frick, Switzerland; IFOAM: Bonn, Germany, 2014; pp. 200-206. Available online: https://orgprints.org/25254/1/schaack-et-al-2014-2014-03-05online.pdf (accessed on 5 March 2014).

26. Kamenidou, I.; Rigas, K.; Priporas, C.V. Household Behavior on Food Security during an Economic Crisis. In Food Security and Sustainability; Mergos, G., Papanastassiou, M., Eds.; Palgrave Macmillan: Cham, Switzerland, 2017; pp. 243-261.

27. HSA. The Greek Economy. Hellenic Republic, Hellenic Statistical Authority Piraeus. 2020. Available online: https://www.statistics.gr/the-greek-economy (accessed on 20 February 2020).

28. HSA. The 2017 Survey on Income and Living Conditions (Income reference period 2016). Press Release, Risk of Poverty, Hellenic Republic, Hellenic Statistical Authority Piraeus. 2018. Available online: http: //www.statistics.gr/documents/20181/1ee23df8-71df-4317-b173-e791d6a15922 (accessed on 22 December 2019).

29. GEMI. Business Deletion Statistics. GENERAL COMMERCIAL REGISTRY. 2020. Available online: http: //backoffice.businessportal.gr/stats/publicity/openings (accessed on 1 February 2020).

30. Amanatidou, E.; Damvakeraki, T.; Karvounaraki, A. RIO Country Report 2017: Greece. Research and Innovation Observatory Country Report Series. 2018. Available online: https://core.ac.uk/download/pdf/ 154760377.pdf (accessed on 22 December 2019).

31. Cavounidis, J. Report No 76: The Emigration of Greeks and Diaspora Engagement Policies for Economic Development; Centre of Planning and Economic Research (KEPE): Athens, Greece, 2016; ISBN 978-960-341-117-8. Available online: https://www.kepe.gr/images/ektheseis/ek_76.pdf (accessed on 22 December 2019).

32. Pratsinakis, M.; Hatziprokopiou, P.; Grammatikas, D.; Labrianidis, L. Crisis and the resurgence of emigration from Greece: Trends, representations, and the multiplicity of migrant trajectories. In European Mobility in Times of Crisis. The New Context of European South-North Migration; Glorius, B., Domínguez-Mujica, J., Eds.; Transcript-Verlag: Bielefeld, Germany, 2017.

33. Ministry of Interior and Administrative Reconstruction. Analysis of Regular Public Administration Personnel for the Year 2015. Greek State Human Resources Registry. 2016. Available online: http:/www.minadmin.gov.gr/ wp-content/uploads/20160318_analisi_metabolon_taktikou_prosopikou2015.pdf (accessed on 25 October 2019).

34. Průša, P.; Sadílek, T. Green Consumer Behavior: The Case of Czech Consumers of Generation, Y. Soc. Mark. Q. 2019, 25, 243-255. [CrossRef]

35. Mannheim, K. The problem of generations. In Karl Mannheim: Essays; Kecskemeti, P., Ed.; Routledge: London, UK, 1952; pp. 276-322.

36. Singh, A.; Singh, G. Cohorts in Marketing: A Review Paper. Int. J. Comput. Appl. 2016. Available online: https://pdfs.semanticscholar.org/0508/af122a76f753065c442aa1547f1c9bae0f18.pdf (accessed on 28 December 2019).

37. Williams, K.C.; Page, R.A. Marketing to the generations. J. Behav. Stud. Bus. 2011, 3, 1-17.

38. O'Neill, M. Generational Preferences: A Glimpse into the Future Office. In Knoll Workplace Research; Koll Inc.: East Greenville, PA, USA, 2010.

39. McCrindle, M.; Wolfinger, E. The ABC of XYZ: Understanding the Global Generations; Chapter 1 "Generations Defined"; University of New South Wales Press Ltd.: Sydney, Australia, 2010. Available online: http://mccrindle.com.au/resources/whitepapers/McCrindle-Research_ABC-01_Generations-Defined_ Mark-McCrindle.pdf (accessed on 15 July 2019).

40. Smola, K.W.; Sutton, C.D. Generational differences: Revisiting generational work values for the new millennium. J. Organ. Behav. 2002, 23, 363-382. [CrossRef]

41. Wohl, R. The Generation of 1914; Harvard University Press: Cambridge, MA, USA, 1979.

42. Schewe, C.D.; Meredith, G. Segmenting global markets by generational cohorts: Determining motivations by age. J. Consum. Behav. Int. Res. Rev. 2004, 4, 51-63. [CrossRef]

43. Pitta, D.; Eastman, J.K.; Liu, J. The impact of generational cohorts on status consumption: An exploratory look at generational cohort and demographics on status consumption. J. Consum. Mark. 2012, 29, $93-102$.

44. Meredith, G.E.; Schewe, C.D.; Karlovich, J. Defining Markets, Defining Moments: America's 7 Generational Cohorts, Their Shared Experiences, and Why Businesses Should Care; John Wiley \& Sons: New York, NY, USA, 2002. 
45. Eastman, J.K.; Iyer, R.; Thomas, S.P. The impact of status consumption on shopping styles: An exploratory look at the millennial generation. Mark. Manag. J. 2013, 23, 57-73.

46. Kupperschmidt, B.R. Multigeneration employees: Strategies for effective management. Health Care Manag. 2000, 19, 65-76. [CrossRef]

47. Kamenidou, I.E.C.; Mamalis, S.A.; Dimitriadis, E. Generation Z perceptions of quality certification: A cross-national study. Int. J. Food Beverage Manuf. Bus. Models 2018, 3, 23-41. [CrossRef]

48. Parment, A. Generation Y vs. Baby Boomers: Shopping behavior, buyer involvement and implications for retailing. J. Retail. Consum. Serv. 2013, 20, 189-199. [CrossRef]

49. Dou, W.; Wang, G.; Zhou, N. Generational and regional differences in media consumption patterns of Chinese generation X consumers. J. Advert. 2006, 35, 101-110. [CrossRef]

50. Freestone, O.; Mitchell, V. Generation Y attitudes towards e-ethics and internet-related misbehaviours. J. Bus. Ethics 2004, 54, 121-128. [CrossRef]

51. Oppermann, D.M. Family life cycle and cohort effects: A study of travel patterns of German residents. J. Travel Tour. Mark. 1995, 4, 23-44. [CrossRef]

52. Tangermann, S. Sustainable food consumption and government responsibility. In International Trade, Consumer Interests and Reform of the Common Agricultural Policy; Routledge: London, UK, 2010; pp. 70-82.

53. Sedlacko, M.; Reisch, L.; Scholl, G. Sustainable food consumption: When evidence-based policy making meets policy-minded research-Introduction to the special issue. Sustain. Sci. Pract. Policy 2013, 9, 1-6. [CrossRef]

54. Priporas, C.-V.; Stylos, N.; Fotiadis, A.K. Generation Z consumers' expectations of interactions in smart retailing: A future agenda. Comp. Hum Behav. 2017, 77, 374-381. [CrossRef]

55. Chaney, D.; Touzani, M.; Ben Slimane, K. Marketing to the (new) generations: Summary and perspectives. J. Strateg. Mark. 2017, 25, 179-189. [CrossRef]

56. Chaudhary, R.; Bisai, S. Factors influencing green purchase behavior of millennials in India. Manag. Environ. Qual. Int. J. 2018, 29, 798-812. [CrossRef]

57. Sa'ari, J.R.; Koe, W.L. The intention to consume organic food among millennial generation. In Proceedings of the Knowledge Management International Conference, Langkawi, Malaysia, 12-15 August 2014; pp. 920-925.

58. Basen, S.E. Effect of economic crisis on food consumption behavior of British Consumers. Int. J. Educ. Res. 2014, 2, 289-316.

59. Stevanin, S.; Voutilainen, A.; Bressan, V.; Vehviläinen-Julkunen, K.; Rosolen, V.; Kvist, T. Nurses' Generational Differences Related to Workplace and Leadership in Two European Countries. West. J. Nurs. Res. 2020, 42, 14-23. [CrossRef] [PubMed]

60. Van Rossem, A.H.D. Generations as social categories: An exploratory cognitive study of generational identity and generational stereotypes in a multigenerational workforce. J. Organ. Behav. 2019, 40, 434-455. [CrossRef]

61. Brink, K.E.; Zondag, M.M. Examining Job Attribute Preferences across Three Generational Cohorts. J. Career Dev. 2019. [CrossRef]

62. McKercher, B.; Lai, B.; Yang, L.; Wang, Y. Travel by Chinese: A generational cohort perspective. Asia Pac. J. Tour. Res. 2020, 25, 341-354. [CrossRef]

63. Eyoun, K.; Chen, H.; Ayoun, B.; Khliefat, A. The relationship between purpose of performance appraisal and psychological contract: Generational differences as a moderator. Int. J. Hosp. Manag. 2020, 86, 102449. [CrossRef]

64. Reisenwitz, T.H.; Fowler, J.G. Information Sources and the Tourism Decision-making Process: An Examination of Generation X and Generation Y Consumers. Glob. Bus. Rev. 2019, 20, 1372-1392. [CrossRef]

65. Chung, J.Y.; Chen, C.C. Generational differences in international stereotypes and destination images: Tourism between partitioned states. J. Travel Tour. Mark. 2019, 36, 865-876. [CrossRef]

66. Cherrez-Ojeda, I.; Mata, V.L.; Vanegas, E.; Felix, M.; Bernstein, J.A.; Jiménez, F.M.; Calderon, J.C.; Chedraui, P.; Gavilanes, A.W. Influence of Generational Cohorts on the Preferences for Information and Communication Technologies in Latin American Patients with Obstructive Lung Diseases. Int. J. Telemed. Appl. 2020. [CrossRef]

67. Zhang, J.; Liu, X.; Zhu, Y.; Yang, L.; Sun, L.; Wei, R.; Chen, G.; Qunan, W.; Sheng, J.; Liu, A.; et al. Antibiotic exposure across three generations from Chinese families and cumulative health risk. Ecotoxicol. Environ. Saf. 2020, 191, 110237. [CrossRef] 
68. Noonan, C.D.; Bunn, J.; Shearin, H. Ranking of the Generic Abilities among Baby Boomer, Generation X, and Millennial Physical Therapists and Physical Therapy Students. Internet J. Allied Health Sci. Pract. 2019, $17,7$.

69. Bourdon, J.L.; Tillman, R.; Francis, M.W.; Dick, D.M.; Stephenson, M.; Kamarajan, C.; Edenberg, H.J.; Kramer, J.; Kuperman, S.; Bucholz, K.; et al. Characterization of service use for alcohol problems across generations and sex in adults with alcohol use disorder. Alcohol. Clin. Exp. Res. 2020. [CrossRef] [PubMed]

70. Lee, Y.J.; Haley, E. How Do Generational Differences Drive Response to Social-Issue Ads? The Effect of Value Orientations across Generations in the US. J. Advert. Res. 2019, 60, 1-18. Available online: http://www.journalofadvertisingresearch.com/content/early/2019/04/24/JAR-2019-013.abstract (accessed on 20 September 2019).

71. Taylor, S., Jr.; DiPietro, R.B. Generational perception and satisfaction differences related to restaurant service environment. Int. J. Hosp. Tour. Adm. 2018, 19, 374-396. [CrossRef]

72. Ostermann, C.M.; Moyano, C.M.; Laufer, J. Brand positioning in higher education: The perception of Brazilian generational cohorts. Revista Brasileira de Gestão de Negócios 2019, 21, 416-434. [CrossRef]

73. Steel, A.; Munk, N.; Wardle, J.; Adams, J.; Sibbritt, D.; Lauche, R. Generational differences in complementary medicine use in young Australian women: Repeated cross-sectional dataset analysis from the Australian longitudinal study on women's health. Complement. Ther. Med. 2019, 43, 66-72. [CrossRef]

74. Diprose, K.; Valentine, G.; Vanderbeck, R.M.; Liu, C.; McQuaid, K. Building common cause towards sustainable consumption: A cross-generational perspective. Environ. Plan. E Nat. Space 2019, 2, $203-228$. [CrossRef]

75. Lissitsa, S.; Kol, O. Four generational cohorts and hedonic m-shopping: Association between personality traits and purchase intention. Electron. Commer. Res. 2019. [CrossRef]

76. Marjanen, H.; Kohijoki, A.-M.; Saastamoinen, K.; Engblom, J. Old dogs learning new tricks? The effect of age and generation on shopping behavior. Int. Rev. Retail Distrib. Consum. Res. 2019, 29, 549-567.

77. Ivanova, O.; Flores-Zamora, J.; Khelladi, I.; Ivanaj, S. The generational cohort effect in the context of responsible consumption. Manag. Decis. 2019, 57, 1162-1183. [CrossRef]

78. Bordonaba-Juste, M.V.; Lucia-Palacios, L.; Pérez-López, R. Generational differences in valuing usefulness, privacy and security negative experiences for paying for cloud services. Inf. Syst. E-Bus Manag. 2020. [CrossRef]

79. Calvo-Porral, C.; Pesqueira-Sanchez, R. Generational differences in technology behaviour: Comparing millennials and Generation, X. Kybernetes 2019. [CrossRef]

80. Lauterbach, F.; De Vries, C.E. Europe belongs to the young? Generational differences in public opinion towards the European Union during the Eurozone crisis. J. Eur. Public Policy 2020, 27, 168-187. [CrossRef]

81. Koksal, M.H. Differences among baby boomers, Generation X, millennials, and Generation Z wine consumers in Lebanon: Some perspectives. Int. J. Wine Bus. Res. 2019, 31, 456-472. [CrossRef]

82. Bezerra, I.N.; Bahamonde, N.M.S.G.; Marchioni, D.M.L.; Chor, D.; de Oliveira Cardoso, L.; Aquino, E.M.; da Conceição, C.; de Almeida, M.; de Jesus, M.; da Fonseca, M.; et al. Generational differences in dietary pattern among Brazilian adults born between 1934 and 1975: A latent class analysis. Public Health Nutr. 2018, 21, 2929-2940. [CrossRef]

83. Wiedmann, K.; Behrens, S.; Klarmann, C.; Hennigs, N. Customer value perception: Cross-generational preferences for wine. Br. Food J. 2014, 116, 1128-1142. [CrossRef]

84. Janssen, M. Determinants of organic food purchases: Evidence from household panel data. Food Qual. Prefer. 2018, 68, 19-28. [CrossRef]

85. Chinnici, G.; D'Amico, M.; Pecorino, B. A multivariate statistical analysis on the consumers of organic products. Br. Food J. 2002, 104, 187-199. [CrossRef]

86. Wägeli, S.; Janssen, M.; Hamm, U. Organic consumers' preferences and willingness-to-pay for locally produced animal products. Int. J. Consum. Stud. 2016, 40, 357-367. [CrossRef]

87. Siegrist, M.; Hartmann, C. Impact of sustainability perception on consumption of organic meat and meat substitutes. Appetite 2019, 132, 196-202. [CrossRef]

88. Da Cunha, D.T.; Antunes, A.E.C.; Da Rocha, J.G.; Dutra, T.G.; Manfrinato, C.V.; Oliveira, J.M.; Rostagno, M.A. Differences between organic and conventional leafy green vegetables perceived by university students: Vegetables attributes or attitudinal aspects? Br. Food J. 2019, 121, 1579-1591. [CrossRef]

89. Steinnes, K.K.; Amilien, V.; Vittersø, G. Organic Salmon in Norway. In Sustainability of European Food Quality Schemes; Springer: Berlin/Heidelberg, Germany, 2019; pp. 529-548. 
90. Butler, G.; Stergiadis, S.; Chatzidimitriou, E.; Franceschin, E.; Davis, H.R.; Leifert, C.; Steinshamn, H. Differing responses in milk composition from introducing rapeseed and naked oats to conventional and organic dairy diets. Sci. Rep. 2019, 9, 8115. [CrossRef]

91. Smith, S.; Paladino, A. Eating clean and green? Investigating consumer motivations towards the purchase of organic food. Australas. Mark. J. 2010, 18, 93-104. [CrossRef]

92. Lian, S.B.; Yoong, L.C. Assessing the Young Consumers' Motives and Purchase Behavior for Organic Food: An Empirical Evidence from a Developing Nation. Int. J. Acad. Res. Bus. Soc. Sci. 2019, 9, 69-87. [CrossRef]

93. Perea, J.; Penedo, I.B.; Barba, C.; Angón, E.; García, A. Organic beef farming in Spain: Typology according to livestock management and economic variables. Revista Científica 2014, 24. Available online: http: //www.fcv.luz.edu.ve/images/stories/revista_cientifica/2014/04/art08.pdf (accessed on 23 October 2019).

94. Krystallis, A.; Fotopoulos, C.; Zotos, Y. Organic consumers' profile and their willingness to pay (WTP) for selected organic food products in Greece. J. Int. Consum. Mark. 2006, 19, 81-106. [CrossRef]

95. Janssen, M.; Schäufele, I.; Zander, K. Target groups for organic wine: The importance of segmentation analysis. Food Qual. Prefer. 2020, 79, 103785. [CrossRef]

96. Lorenz, B.A.; Langen, N. Determinants of how individuals choose, eat and waste: Providing common ground to enhance sustainable food consumption out-of-home. Intern. J. Consum. Stud. 2018, 42, 35-75. [CrossRef]

97. Rana, J.; Paul, J. Consumer behavior and purchase intention for organic food: A review and research agenda. J. Retail. Consum. Serv. 2017, 38, 157-165. [CrossRef]

98. Rödiger, M.; Hamm, U. How are organic food prices affecting consumer behaviour? A review. Food Qual. Prefer. 2015, 43, 10-20. [CrossRef]

99. Hemmerling, S.; Hamm, U.; Spiller, A. Consumption behaviour regarding organic food from a marketing perspective-A literature review. Org. Agric. 2015, 5, 277-313. [CrossRef]

100. Lairon, D. Nutritional quality and safety of organic food. A review. Agron. Sustain. Dev. 2010, 30, 33-41. [CrossRef]

101. Tsay, Y.Y. The impacts of economic crisis on green consumption in Taiwan. In Proceedings of the PICMET'09-2009 Portland International Conference on Management of Engineering \& Technology, Portland, OR, USA, 2-6 August 2009; pp. 2367-2374.

102. Molinillo, S.; Vidal-Branco, M.; Japutra, A. Understanding the drivers of organic foods purchasing of millennials: Evidence from Brazil and Spain. J. Retail. Consum. Serv. 2020, 52, 101926. [CrossRef]

103. Bollani, L.; Bonadonna, A.; Peira, G. The Millennials' Concept of Sustainability in the Food Sector. Sustainability 2019, 11, 2984. [CrossRef]

104. Leerattanakorn, N. Determinants of Green Consumption of Generation Y in Chiang Mai, Thailand. MFU Connex. 2017, 6, 1-21. Available online: http://connexion.mfu.ac.th/assets/uploads/ejournal/Vol.6\%20No.2\% 202017/1-21\%20Determinants\%20of\%20Green\%20Consumption.pdf (accessed on 27 November 2019).

105. Vidal-Branco, M.; Molinillo, S.; Japutra, A.; Longaray, A. Organic Food Purchasing of the Millennials Generation: Case of Brazil. In Omnichannel Marketing: Las Nuevas Reglas de la Distribución y el Consumo en un Mundo Omnicanal; Cátedra Fundación Ramón Areces de Distribución Comercial: Asturias, Spain, 2019; pp. 331-348.

106. Muposhi, A.; Surujlal, J.; Dhurup, M. The green dilemma: Reflections of a Generation Y consumer cohort on green purchase behaviour. TD J. Transdiscipl. Res. South. Afr. 2015, 11, 225-240. [CrossRef]

107. Hassan, S.H.; Yee, L.W.; Ray, K.J. Purchasing intention towards organic food among generation $Y$ in Malaysia. J. Agribus. Mark. (Malaysia) 2015, 7, 16-32.

108. Muposhi, A.; Dhurup, M. A qualitative inquiry of generation $Y$ consumers' selection attributes in the case of organic products. Int. Bus. Econ. Res. J. (Online) 2016, 15. [CrossRef]

109. Thambiah, S.; Khin, A.A.; Muthaiyah, S.; Yen, Y.Y. Organic food consumption among Generation Y in Malaysia: A conceptual framework. J. Appl. Sci. 2015, 15, 570-575. [CrossRef]

110. Pomarici, E.; Vecchio, R. Millennial generation attitudes to sustainable wine: An exploratory study on Italian consumers. J. Clean. Prod. 2014, 66, 537-545. [CrossRef]

111. Regine, K.M. Generation Y consumer choice for organic foods. J. Glob. Bus. Manag. 2011, 7, 1-13. Available online: http://www.jgbm.org/page/6\%20Kristen\%20Regine.pdf (accessed on 19 November 2019).

112. Pearson, D.; Henryks, J.; Rowe, P. Sustainable consumption in Australia: What do Generation Y consumers know about their food choices. In Proceedings of the Australian and New Zealand Marketing Academy (ANZMAC) Conference, Christchurch, New Zealand, 29 November-2 December 2010. 
113. Ntanos, A.; Skordoulis, M.; Ntanos, S. Millennial consumers' perceptions on the organic products. In Proceedings of the International Scientific Conference eRA-9, Piraeus, Greece, 22-24 September 2014; pp. 26-35.

114. Su, C.H.J.; Tsai, C.H.K.; Chen, M.H.; Lv, W.Q. US Sustainable Food Market Generation Z Consumer Segments. Sustainability 2019, 11, 3607. [CrossRef]

115. Gil, J. Market segmentation and willingness to pay for organic products in Spain. Int. Food Agribus. Manag. Rev. 2000, 3, 207-226. [CrossRef]

116. Magnusson, M.K.; Arvola, A.; Koivisto Hursti, U.K.; Åberg, L.; Sjödén, P.O. Attitudes towards organic foods among Swedish consumers. Br. Food J. 2001, 103, 209-227. [CrossRef]

117. Nickel, B.; Berger, M.; Schmidt, P.; Plies, K. Qualitative Sampling in a Multi- method Survey: Practical Problems of Method Triangulation in Sexual Behavior Research. Qual. Quant. 1995, 29, 223-240. [CrossRef]

118. Patton, M.Q. Qualitative Evaluation and Research Methods; Sage: London, UK, 1990.

119. Creswell, J.W.; Miller, D.L. Determining validity in qualitative inquiry. Theory Pract. 2000, 39, $124-130$. [CrossRef]

120. Kent, R. Marketing Research in Action; Routledge: London, UK, 1993.

121. Spector, P.E. Summated Rating Scale Construction: An Introduction; Sage University Paper Series No.82, on Quantitative Applications in the Social Sciences; Sage: Beverly Hills, CA, USA, 1992.

122. Fornell, C.; Larcker, D.F. Evaluating structural equation models with unobservable variables and measurement error. J. Mark. Res. 1981, 18, 39-50. [CrossRef]

123. Sogari, G.; Velez-Argumedo, C.; Gómez, M.; Mora, C. College students and eating habits: A study using an ecological model for healthy behavior. Nutrients 2018, 10, 1823. [CrossRef]

124. Abraham, S.; Noriega, B.R.; Shin, J.Y. College students eating habits and knowledge of nutritional requirements. J. Nutr. Hum. Health 2018, 2, 13-17. [CrossRef]

125. Organic Trade Association. Millennials and Organic: A Winning Combination. 2016. Available online: https://www.ota.com/news/press-releases/19256 (accessed on 4 December 2019).

126. Gurau, C. A life-stage analysis of consumer loyalty profile: Comparing Generation $X$ and Millennial consumers. J. Consum. Mark. 2012, 29, 103-113. [CrossRef]

127. Wandel, M.; Bugge, A. Environmental concern in consumer evaluation of food quality. Food Qual. Prefer. 1997, 8, 19-26. [CrossRef]

128. Chen, M.F. Attitude toward organic foods among Taiwanese as related to health consciousness, environmental attitudes, and the mediating effects of a healthy lifestyle. Br. Food J. 2009, 111, 165-178. [CrossRef]

129. Ang, S.H.; Leong, S.M.; Kotler, P. The Asian Apocalypse: Crisis Marketing for Consumers and Businesses. Long Range Plan. 2000, 33, 97-119. [CrossRef]

130. See, S.Z.; Mansori, S. Young Female Motivations for Purchase of Organic Food in Malaysia. Int. J. Contemp. Bus. Stud. 2012, 3, 61-72.

131. Pham, T.H.; Nguyen, T.N.; Phan, T.T.H.; Nguyen, N.T. Evaluating the purchase behavior of organic food by young consumers in an emerging market economy. J. Strateg. Mark. 2019, 27, 540-556. [CrossRef]

132. Wang, L.; Wang, J.; Huo, X. Consumer's Willingness to Pay a Premium for Organic Fruits in China: A Double-Hurdle Analysis. Int. J. Environ. Res. Public Health 2019, 16, 126. [CrossRef]

133. Kyriakopoulos, K.; van Dijk, G. Post-purchase intentions for organic foodstuff: A conceptual framework based on the perception of product value. J. Int. Food Agribus. Mark. 1997, 9, 1-19. [CrossRef]

134. Zavali, M.; Theodoropoulou, H. Investigating determinants of green consumption: Evidence from Greece. Soc. Responsib. J. 2018, 14, 719-736. [CrossRef]

135. Lodorfos, G.; Konstantopoulou, A.; Kostopoulos, I.; Essien, E.E. Food and Drink Industry in Europe and Sustainability Issues. In The Sustainable Marketing Concept in European SMEs; Rudawska, E., Ed.; Emerald Publishing Limited: Bingley, UK, 2018; pp. 121-140.

136. Krystallis, A.; Chryssohoidis, G. Consumers' willingness to pay for organic food: Factors that affect it and variation per organic product type. Br. Food J. 2005, 107, 320-343. [CrossRef]

137. Duquenne, M.N.; Vlontzos, G. The impact of the Greek crisis on the consumers' behaviour: Some initial evidences? Br. Food J. 2014, 116, 890-903. [CrossRef]

138. Casini, L.; Contini, C.; Romano, C.; Scozzafava, G. Trends in food consumptions: What is happening to generation X? Br. Food J. 2015, 117, 705-718. [CrossRef] 
139. Yin, S.; Chen, M.; Chen, Y.; Xu, Y.; Zou, Z.; Wang, Y. Consumer trust in organic milk of different brands: The role of Chinese organic label. Br. Food J. 2016, 118, 1769-1782. [CrossRef]

140. Janssen, M.; Hamm, U. Governmental and private certification labels for organic food: Consumer attitudes and preferences in Germany. Food Policy 2014, 49, 437-448. [CrossRef]

141. Seyrek, I.H.; Gul, M. Factors Affecting Green Purchasing Behavior: A Study of Turkish Consumers. Int. J. Acad. Res. Bus. Soc. Sci. 2017, 7, 306-319. [CrossRef]

142. Tripathi, A.; Singh, M.P. Determinants of sustainable/green consumption: A review. Int. J. Environ. Technol. Manag. 2016, 19, 316-358. [CrossRef]

143. Kotler, P.; Roberto, N.; Lee, N. Social Marketing: Improving the Quality of Life, 2nd ed.; Sage Publications: Thousand Oaks, CA, USA, 2002.

144. Power, K. Introducing Behaviour Changes towards Sustainable Food Consumption. CORPUS: The SCP Knowledge Hub. 2010. Available online: www.scp-knowledge.eu/sites/default/files/knowledge/attachments/ KU_Introducing_behaviour_changes.pdf (accessed on 17 August 2019).

145. Bogueva, D.; Marinova, D.; Raphaely, T. Reducing meat consumption: The case for social marketing. Asia Pac. J. Mark. Logist. 2017, 29, 477-500. [CrossRef]

146. Peattie, K. Green Consumption: Behavior and Norms. Annu. Rev. Environ. Resour. 2010, 35, $195-228$. [CrossRef]

147. Nuttavuhosot, K.; Thogersen, J. The Importance of Consumer Trust for the Emergence of a Market for Green Products: The Case of Organic Food. J. Bus Ethics 2017, 140, 323-337. [CrossRef]

148. Lau, H.; Shum, P.K.; Nakandala, D.; Fan, Y.; Lee, C. A game theoretic decision model for organic food supplier evaluation in the global supply chains. J. Clean. Prod. 2020, 242, 118536. [CrossRef]

149. Daugbjerg, C.; Smed, S.; Andersen, L.M.; Schvartzman, Y. Improving eco-labelling as an environmental policy instrument: Knowledge, trust and organic consumption. J. Environ. Policy Plan. 2014, 16, 559-575. [CrossRef]

150. Dabbert, S. Measuring and communicating the environmental benefits of organic food production. Crop Manag. 2006, 5. Available online: https://dl.sciencesocieties.org/publications/cm/abstracts/5/1/CM-2006-0921-13-RV (accessed on 3 November 2019). [CrossRef]

151. Kareklas, I.; Carlson, J.R.; Muehling, D.D. "I eat organic for my benefit and yours": Egoistic and altruistic considerations for purchasing organic food and their implications for advertising strategists. J. Advert. 2014, 43, 18-32. [CrossRef]

152. Madden, C. Hello Gen Z: Engaging the Generation of Post-Millennials; Revised Edition; Hello Clarity: Sydney, Australia, 2017.

153. Mont, O. Sustainable Consumption Policies Effectiveness Evaluation (SCOPE2): Analysis of Identified Gaps; TNO Built Environment and Geosciences: Delft, The Netherlands, 2008. Available online: http://old.seri.at/ documentupload/Homepage\%20SERI\%20D/d4b_scope2_gapanalysispdf.pdf (accessed on 23 September 2019).

154. Strong, C. The impact of environmental education on children's knowledge and awareness of environmental concerns. Mark. Intell. Plan. 1998, 16, 349-355. [CrossRef]

155. Beltrán, S.L. Segmentación de los consumidores de alimentos orgánicos según sus actitudes, valores y creencias ambientales. Contaduría y Administración 2019, 64, e98. [CrossRef]

156. Díaz Víquez, A.; Pérez Hernández, A.; Hernández Ávila, J. Caracterización del consumidor de productos orgánicos en la ciudad de Toluca. Revista Mexicana de Agronegocios 2015, 19, 1178-1187.

157. Haase, J.; Wiedmann, K.P.; Bettels, J.; Labenz, F. How to best promote my product? Comparing the effectiveness of sensory, functional and symbolic advertising content in food marketing. Br. Food J. 2018, 120, 1792-1806. [CrossRef]

158. Contreras, J.; Gracia, M. (Eds.) Alimentación y Cultura. Perspectivas Antropológicas; Ariel: Barcelona, Spain, 2005; pp. 387-392. [CrossRef]

(C) 2020 by the authors. Licensee MDPI, Basel, Switzerland. This article is an open access article distributed under the terms and conditions of the Creative Commons Attribution (CC BY) license (http://creativecommons.org/licenses/by/4.0/). 